\title{
Popular Song and the Poetics of Experience
}

\author{
ROSS COLE
}

\begin{abstract}
This article argues that songwriting can be an autobiographical activity. I trace a longstanding mistrust of self-expression in popular music through a branch of scholarship fixated with performance and personification, demonstrating its underlying affinities with post-structuralism and modernist dreams of impersonality. What we have lost as a result of this undue insistence on mediation is an awareness of the two-way traffic between life and lyrical craft. A poetics of song should pay increased attention to this intricate relationship - not reducing lyrics to biographical contingencies, but rather viewing autobiography itself as a complex process of self-reading, a public act of autobiographical making. My argument is illustrated with reference to three contemporary singer-songwriters who have interpreted aspects of their lives through song: Vic Chesnutt, Sun Kil Moon (Mark Kozelek) and Anohni (formerly of Antony and the Johnsons). Their work ultimately traverses and obscures the interstices between experience and imagination.
\end{abstract}

When we hear a song it also seems to hear us. As we enter the world of a song, allowing it to infringe momentarily on our consciousness, we yield and the song begins to lead us - perhaps unwillingly, perhaps unwittingly - down unexpected pathways bent in the undergrowth of reminiscence and imagination. Rather than attentive listening contributing to the process of interpreting a song, in other words, songs appear to interpret us as we listen to them: they uncover or disarm us, they divert us and they move us by somehow trespassing over the landscapes of memory that we keep hidden away amid our day-to-day lives, illuminating the recesses of the self. Songs, we might say, are theatres of emotion played out alone and in private. As Jean-Jacques Nattiez attests, musical traces do not communicate in a linear fashion from producer to receiver; a semiotics of music instead draws attention to the receiver's agency in a dynamic relationality of response. ${ }^{1}$

Email: rgc30@cam.ac.uk

This article evolved from discussions over dinner with my family while listening to Janis Ian and has been a long time in the making. I would like to thank Gavin Alexander, Nicholas Cook, Keith Negus and Chris Townsend for reading early drafts. Thanks also to the anonymous reviewers for this journal, members of the Cambridge Interdisciplinary Song Seminar and those who offered comments on my paper at the Crosstown Traffic IASPM conference in September 2018 and the colloquium I gave at King's College London in October 2018.

1 Jean-Jacques Nattiez, Music and Discourse: Towards a Semiology of Music, trans. Carolyn Abbate (Princeton, NJ: Princeton University Press, 1990), 17-18.

(C) The Author(s), 2021. Published by Cambridge University Press on behalf of The Royal Musical Association. This is an Open Access article, distributed under the terms of the Creative Commons Attribution licence (http://creativecommons.org/licenses/by/4.0/), which permits unrestricted re-use, distribution, and reproduction in any medium, provided the original work is properly cited. 
But this is only half the story - what Nattiez (after Paul Valéry) labels as the 'esthesic' dimension in which listeners perceive the meaning of something through their own lived experience. The 'poietic' dimension of a work, on the other hand, points towards a 'process of creation that may be described or reconstituted'. ${ }^{2}$ This poetic focus is concerned above all with acts of making and making sense. It works in the opposite direction to the kind of hermeneutic or historicist scholarship that became de rigueur with the rise of 'new' musicology and still holds a powerful sway over much writing and teaching in the academy today. ${ }^{3}$ To quote Jonathan Culler, poetics is less concerned with context or what texts mean than how their effects are achieved, seeking to understand 'the techniques that make meaning possible'. ${ }^{4}$ Culler uses this tactic to question a deep-rooted reflex in which lyric poems are treated as theatrical scenarios or narratives. Whereas Culler is primarily interested in lyric's linguistic intrigue, its playful preoccupations with language, this article seeks to rehabilitate an idea too often consigned to lively speculation in the public sphere: that songwriting can be autobiographical. I am less concerned with autobiographical readings of songs, however, than with the ways in which songwriting itself can be a process of self-interpretation, a public act of autobiographical making.

I begin by tracing a long-standing mistrust of self-expression in song through a branch of popular music scholarship fixated with performance and personification. Much is lost, Culler writes, in this habitual recourse to personae - most obviously those 'aspects of lyric that exceed dramatic monologue'. ${ }^{5}$ One of these aspects, I want to suggest, is the vexed relationship between art and life. After a section introducing the idea of autobiography as a form of self-reading, this article focuses in detail on recent recordings by three contemporary artists, all of whom have chosen to read aspects of their lives through song: Vic Chesnutt, Sun Kil Moon and Anohni. Respectively, these figures will allow us to trace three different facets of autobiography: epitaph, particularity and testimony. Like that of many other artists since the advent of the singersongwriter idiom during the 1960s, their work implores us to make connections between song and subjectivity, personhood and performance. Such understanding comes to affect how we hear this material, delivering an acoustic correlative of what Roland Barthes refers to in photography as the acutely poignant punctum of realism - a contingent detail that overwhelms the mundane and marks, in his words, 'an intense mutation of my interest, a fulguration [...] a satori' ${ }^{6}$ If songwriting can indeed become an autobiographical act of reading and making, then we must ask ourselves what the

2 Nattiez, Music and Discourse, 12 (emphasis original).

3 For an overview, see Nicholas Cook, 'Theorizing Musical Meaning', Music Theory Spectrum, 23 (2001), 170-95. Richard Taruskin made it his mission to counter what he felt were the shortcomings of this approach: see Taruskin, 'The Poietic Fallacy', Musical Times, 145/1886 (2004), 7-34.

4 Jonathan Culler, Theory of the Lyric (Cambridge, MA: Harvard University Press, 2015), 6. See also Peter Brooks, 'Aesthetics and Ideology: What Happened to Poetics?', Critical Inquiry, 20 (1994), 509-23.

5 Jonathan Culler, 'The Language of Lyric', Thinking Verse, 4 (2014), 160-76 (p. 176).

6 Roland Barthes, Camera lucida: Reflections on Photography, trans. Richard Howard (London: Vintage, 2000), 49. 
implications - and historical motivations - are for prevailing theories of personification, impersonality and aesthetic autonomy.

\section{Performance, personae, post-structuralism}

In 1996, Simon Frith laid the groundwork for a new approach to the evaluation of popular song in his book Performing Rites. ${ }^{7}$ Frith's concern was to accentuate what scholars of popular music were at risk of overlooking in the nascent field. The hint was in his title: what the book argued for, broadly, was increased attention to live or recorded performance, ritual, orality, vocality, theatricality, pleasure, reception and embodiment. Frith understood that pop music was something more than an assortment of written texts, more than mere words on a page, more than poetry's poor cousin. The kind of stance that Frith had decided to take aim at was epitomized by works such as Michael Gray's Song and Dance Man: The Art of Bob Dylan, first published in 1972 and reprinted in expanded form a decade later and again in $2000 .^{8}$ Gray's book, Frith argues, is 'a tour-de-force ragout of pop criticism, New Criticism, and Leavisism' unhelpfully mired in the elitist values of literary modernism a theme to which we shall return. ${ }^{9}$ Frith's antidote to this propensity to locate meaning solely in the written lyrics was to emphasize that, 'How words work in song depends not just on what is said, the verbal content, but also on how it is said - on the type of language used and its rhetorical significance; on the kind of voice in which it is spoken.' ${ }^{10}$ In short, expression, characterization, role play and performance are just as integral to establishing a song's meaning as the minutiae of lyrical craft.

Frith developed this idea by arguing that the voice we hear in popular song is always multifaceted, at once a versatile musical instrument mediated by microphone and/or studio technology, the signifier of a particular body (with all those ingrained overtones of race, gender, sexuality and eroticism) and something more mercurial or deceptive. He encourages us to take heed of a 'multiplicity of voices' brought to life through performance incorporating 'the protagonist of the song', 'a "quoted" [or interpolated] character', 'the singer as star' and finally 'the singer as a person [...] a physicality that overflows the formal constraints of the performance' ${ }^{11}$ What emerges is a reading of popular music as an entanglement of voices in which a performer 'draws attention to performance itself, to the relationship between performer and work'. ${ }^{12}$ In other words, although we often hear songs as archetypes of intimate self-revelation, they are in fact complex inventions on the part of singers, who behave more like stage actors

7 Simon Frith, Performing Rites: Evaluating Popular Music (Oxford: Oxford University Press, 1996).

8 Michael Gray, Song and Dance Man: The Art of Bob Dylan (London: Hart-Davis, MacGibbon, 1972); Gray, The Art of Bob Dylan: Song and Dance Man, new edn (London: Hamlyn, 1981); Gray, Song and Dance Man III: The Art of Bob Dylan, 3rd edn (London: Cassell, 2000).

9 Frith, Performing Rites, 177.

10 Ibid., 163-4 (emphasis added).

11 Ibid., 198-9, 212 (emphasis original).

12 Ibid., 200 (emphasis original). Here Frith is drawing on Edward T. Cone, The Composer's Voice (Berkeley, CA: University of California Press, 1974), and Carolyn Abbate, Unsung Voices: Opera and Musical Narrative in the Nineteenth Century (Princeton, NJ: Princeton University Press, 1991). 
or film stars than confessional poets. In this light, songs are best seen as plays or 'minimusicals' - an inherently 'dramatic form' involving enactments of self and other. ${ }^{13}$ It would hence be rather 'stupid', as Frith puts it, to suggest that what we hear in song is the singer's own voice: sincerity, he insists, 'cannot be measured by searching for what lies behind the performance'. ${ }^{14}$ We might term this the 'performance studies' approach to the study of popular song.

The performance studies approach that Frith outlined fared remarkably well in the decades following the publication of Performing Rites, becoming a familiar trope attesting to a wider performative turn across the humanities. In 2004, for instance, the performance studies scholar Philip Auslander published a 'manifesto' that explicitly sought to 'systematize and expand on Frith's account', beginning with the critical assumption that, 'We must be suspicious of any supposition that musicians are simply "being themselves" on stage. ${ }^{15}$ Instead, Auslander argues, popular song involves three 'signified presences' or 'layers of performance': 'the real person (the performer as human being), the performance persona (which corresponds to Frith's star personality or image) and the character (Frith's song personality)'. ${ }^{16}$ Auslander's contribution was to emphasize the idea of an artistic persona, a term identifying a dramatic construction (neither self nor enacted character) which applies not only to pop singers but also to jazz and classical musicians - a role intimately bound up with industry, social convention and audience expectation. Such personae, David Shumway notes, are tied up in conceptions of authenticity indexed not by a concrete 'relation to the biographical subject who inhabits that image', but by the image itself: 'Stars are performers, and to perform is to step into a role that is not one's self.' ${ }^{\prime 7}$ In Auslander's scheme, the persona is an ambiguous bridge between a real person (to whom we have little or no direct access) and a song's implied character.

We find Frith cited again in Auslander's subsequent work on musical personae in which he affirms, 'What is important [in song] is that the performer appear to be feeling and expressing certain emotions. ' ${ }^{18}$ At this point, Auslander brings Nicholas Cook into the mix, dismissing his idea of a socially embedded 'script' as a 'dead end' harbouring an implicit bias towards the traditional work concept. ${ }^{19}$ For Auslander, what matters is not the relationship between performer and text, but that between performer,

13 Frith, Performing Rites, 211-12.

14 Ibid., 184, 215 (emphasis original).

15 Philip Auslander, 'Performance Analysis and Popular Music: A Manifesto', Contemporary Theatre Review, 14/1 (2004), 1-13 (p. 6).

16 Ibid. A similar theory of musical personae was developed concurrently by Jeanette Bicknell in 'Just a Song? Exploring the Aesthetics of Popular Song Performance', Journal of Aesthetics and Art Criticism, 63 (2005), 261-70. Much like Auslander, Bicknell draws on Stan Godlovitch, Musical Performance: A Philosophical Study (London: Routledge, 1998) - in particular, on his notion of 'personalism' (pp. 139-44).

17 David R. Shumway, 'Authenticity: Modernity, Stardom, and Rock \& Roll', Modernism/Modernity, 14 (2007), 527-33 (pp. 528, 530).

18 Philip Auslander, 'Musical Personae', The Drama Review, 50/1 (spring 2006), 100-19 (p. 112; emphasis original).

19 Ibid., 101. See Nicholas Cook, 'Between Process and Product: Music and/as Performance', Music Theory Online, 7/2 (2001), <http://www.societymusictheory.org/mto/issues/mto.01.7.2/ 
spectator, space and genre - in short, between performer and social context. His approach is 'unabashedly performer-centric' and results in the nebulous and selfserving idea that, 'What musicians perform first and foremost is not music, but their own identities as musicians, their musical personae.' ${ }^{20}$ This scheme downplays the 'real person' to such an extent that they disappear behind a veil of sociology and spectacle, and musical performance is reduced to a mere 'species of performance of identity'. ${ }^{21}$ Much like the word mediation when overused, performance in this guise becomes increasingly ineffectual as a heuristic: everything, it seems, is performed, just as everything is inescapably mediated. As Cook reminds us, moreover, such a scheme is in danger of ignoring the defining feature of literate musical culture. ${ }^{22}$ To put it bluntly, when Bob Dylan performs 'Stuck Inside of Mobile with the Memphis Blues Again' (especially when captured on record) he is performing not only his identity, but also something we recognize as 'Stuck Inside of Mobile with the Memphis Blues Again' by Bob Dylan.

The Frith-Auslander thesis nonetheless presents us with a persuasive argument: what we hear in popular song is not honest personal confession, but a staged process of identity formation and performative masquerade in which a singer actively responds to the demands of an audience, whose members invest (both emotionally and financially) in a celebrity persona that may bear very little relation to the person behind the maskwho in any case exists within a mise en abime of interiority whereby, according to Wendy Doniger, 'As we go deeper and deeper through the alternating layers of masks and faces, we never reach a monolithic core. ${ }^{23}$ It is an argument that suits the Adornian sceptic, the academic theorist who refuses to be duped or enchanted by the mesmeric claims of mass culture. Thus, Shumway can unmask Joni Mitchell's 'confessional persona' in her early work as simply 'a performed role'. ${ }^{24}$ Similarly, Ariana PhillipsHutton can argue that a singer-songwriter who confesses to 'uncomfortable lyrical selfdisclosure' is actually engaged in a socially mediated performance practice that results in 'a persona that plays on ideas of self-revelation, truth-telling, vulnerability and emotional connection'. ${ }^{25}$ Indeed, she advises that 'we must maintain the distinction between William Fitzsimmons as a human being and as a performer' even though listeners' enjoyment of his music is predicated on collapsing this very distinction. ${ }^{26}$

mto.01.7.2.cook_frames.html> (accessed 1 May 2019), and Lydia Goehr, The Imaginary Museum of Musical Works: An Essay in the Philosophy of Music (Oxford: Clarendon Press, 1992).

20 Auslander, 'Musical Personae', 102-3.

21 Ibid., 117. Auslander is drawing heavily here on the work of Erving Goffman.

22 See Nicholas Cook, Beyond the Score: Music as Performance (Oxford: Oxford University Press, 2013), 336.

23 Wendy Doniger, 'Many Masks, Many Selves', Daedalus, 135/4 (autumn 2006), 60-71 (p. 70). For an example of this kind of analysis, see Lee Marshall, Bob Dylan: The Never Ending Star (Cambridge: Polity, 2007).

24 David R. Shumway, Rock Star: The Making of Musical Icons from Elvis to Springsteen (Baltimore, MD: Johns Hopkins University Press, 2014), 149, 151. It is telling that the terms 'biography' and 'autobiography' are both absent from Shumway's index.

25 Ariana Phillips-Hutton, 'Private Words, Public Emotions: Performing Confession in Indie Music', Popular Music, 37 (2018), 329-50 (p. 344).

26 Ibid., 339-40. 
Allan Moore likewise employs this performance studies paradigm to submit that 'rather than imagine that we are listening to an individual singing to us, an individual able to express himself or herself directly, and through whose expression we understand his or her subjectivity', it is more appropriate 'to recognize that we are listening to a persona, projected by a singer' - an 'artificial construction' fashioned through performance, 'personic environment' and studio technique. ${ }^{27}$ Moore arrived at this conclusion in the early 1990s via precisely the same route as Frith, deriving his ideas on personification and expressive mediation from Edward Cone's 1974 book The Composer's Voice. As Cone writes in reference to Western art music, 'The persona is by no means identical with the composer; it is a projection of his musical intelligence, constituting the mind, so to speak, of the composition in question. ${ }^{28}$ Moore had pioneered the application of this theory to popular music studies. In Rock: The Primary Text he uses Cone to bolster his argument that 'a simple model which proposes that musicians express themselves in unmediated communication with an audience does not stand up to scrutiny' - a claim later echoed by Matthew Gelbart in his analysis of personification in the Kinks' songs of the late 1960s. ${ }^{29}$

Despite this performance studies approach highlighting process over product and performance over text, it dovetails with a well-known strand in literary criticism associated with Francophone post-structuralism. ${ }^{30}$ Their point of intersection is a shared suspicion of autobiographical candour. A classic case in point is Barthes's Roland Barthes - an autobiography prefaced with the epigraph, 'It must all be considered as if spoken by a character in a novel.' Roland Barthes tells us that any attempt to write autobiographically is a failure on account of language itself:

For the image-repertoire, fatal substance of the novel, and the labyrinth of levels in which anyone who speaks about himself gets lost - the image-repertoire is taken over by several masks (personae), distributed according to the depth of the stage (and yet no one personne, as we say in French - is behind them). ${ }^{31}$

Language, somewhat counter-intuitively, 'forbids me to "express myself"; instead, it exposes 'the inconsistency of the subject, his atopia, dispersing the enticements of the imaginary, it makes all lyricism untenable (as the utterance of a central "emotion")'. 32 Revealing a displaced and decentred subject adrift in an inhospitable landscape of

27 Allan F. Moore, Song Means: Analysing and Interpreting Recorded Popular Song (Farnham: Ashgate, 2012), 179.

28 Cone, The Composer's Voice, 57; see also p. 18.

29 Allan F. Moore, Rock: The Primary Text (Buckingham: Open University Press, 1993), 163; Matthew Gelbart, 'Persona and Voice in the Kinks' Songs of the Late 1960s', Journal of the Royal Musical Association, 128 (2003), 200-41. Cone's work is also referenced in Nicola Dibben, 'Subjectivity and the Construction of Emotion in the Music of Björk', Music Analysis, 25 (2006), 171-97.

30 The exception here is Shumway's Rock Star, which is based on the assumption that 'star personas are complex and meaningful texts that require the kind of interpretive exploration we devote to other works of art' (p. xiii). This statement is a clear demonstration of the hidden textual underpinnings of the performance studies approach to popular culture.

31 Roland Barthes, Roland Barthes, trans. Richard Howard (New York: Hill \& Wang, 2010), 119-20 (emphasis original).

32 Ibid., 86. 
words, autobiography is thus 'totally fictive', an act of duplicity or masquerade - an untethered simulacrum floating above the disorderly realm of existence. ${ }^{33}$

Barthes was not alone in holding such views. Although Michel Foucault felt the need to challenge the idea of writing-as-absence as it seemed to maintain 'the author's privileges under the protection of writing's a priori status', he endorsed a similar position. ${ }^{34}$ Given that a textual 'I' gives rise to a variety of possible subject positions, he claims, 'it would be just as wrong to equate the author with the real writer as to equate him with the fictitious speaker' of a novel: the term 'author', therefore, 'does not refer purely and simply to a real individual'. ${ }^{35}$ Foucault's aim instead was to recognize the author as an 'ideological figure' marking 'the manner in which we fear the proliferation of meaning' - a nominal function serving to identify the bounds of texts and discursive formations. ${ }^{36}$ For Gaston Bachelard, in contrast, what was at stake were the limits of a psychologizing form of criticism that attempted incorrectly, as it were, to explain 'the flower by the fertilizer'; poetry, conversely, 'stands out from life to such an extent that life cannot explain it'. ${ }^{37}$ What Bachelard underscored was that biographical or historicist explanations of literature were always reductive or redundant as they neglected to factor in not only phenomenology but also that most valuable and enigmatic aspect of human expression, the creative imagination. Ultimately, to borrow Paul de Man's words from a well-known essay on the subject, autobiography emerged from the post-structuralist moment as a 'disreputable' genre predicated on a fictive process of privation and disfigurement grounded in the trope of prosopopoeia ("positing voice or face by means of language'). ${ }^{38}$

Such ideas found their most iconic form in Barthes's notorious polemic encouraging the birth of an active reader under the waning tyranny of logocentric criticism. In 'The Death of the Author' he asserts that, 'Writing is that neutral, composite, oblique space where our subject slips away, the negative where all identity is lost, starting with the very identity of the body writing.' 39 Through writing, in other words, 'It is language which speaks, not the author; to write is, through a prerequisite impersonality [...] to reach that point where only language acts, "performs", and not "me". 40 What Barthes

33 Ibid., 120; see Jean Baudrillard, Simulacra and Simulation, trans. Sheila Faria Glaser (Ann Arbor, MI: University of Michigan Press, 1994).

34 Michel Foucault, 'What is an Author?', trans. Josué V. Harari in The Foucault Reader, ed. Paul Rabinow (London: Penguin, 1991), 101-20 (p. 105). 'To imagine writing as absence,' he argues, 'seems to be a simple repetition, in transcendental terms, of both the religious principle of inalterable and yet never fulfilled tradition, and the aesthetic principle of the work's survival, its perpetuation beyond the author's death, and its enigmatic excess in relation to him' (ibid.; emphasis original). Ibid., 112-13.

Ibid., 119.

37 Gaston Bachelard, The Poetics of Space, trans. Maria Jolas (New York: Penguin, 2014), 14, 17.

38 Paul de Man, 'Autobiography as De-facement', Modern Language Notes, 94 (1979), 919-30 (pp. 919, 930). See also Gavin Alexander, 'Prosopopoeia: The Speaking Figure', Renaissance Figures of Speech, ed. Sylvia Adamson, Gavin Alexander and Katrin Ettenhuber (Cambridge: Cambridge University Press, 2007), 97-112.

39 Roland Barthes, 'The Death of the Author', Image-Music-Text, trans. Stephen Heath (London: Fontana Press, 1977), 142-8 (p. 142).

$40 \quad$ Ibid., 143. 
is claiming, at its most basic, is that writing and language are not self-revelatory but in fact performative - a theory recalling ideas put forward by J. L. Austin in his seminal book How to Do Things with Words. ${ }^{41}$ It is via this notion of performativity that performance studies and literary theory meet in their mutual mistrust of autobiography. For literary theory, it is language that brings things into being (characters, a lyrical protagonist, a voice), whereas for performance studies, performance brings things into being (whether personae, identity or emotion). Either way, what is brought to life appears to bear little relation to the world 'outside' or 'behind' a text or performance with the consequence that popular song is rendered as a kind of surface without depth, a deception. In this way, performance studies inadvertently echoes the discourse of textual autonomy it yearns to escape.

\section{Orphism and autobiography}

What Frith argued for in 1996 was necessary at the time to counterbalance a narrowly textual reading of popular culture. ${ }^{42}$ Yet, as we have seen, this new approach not only tipped the balance too far in the other direction (away from words entirely towards music being a mere performance of social identity), but also ended up reinforcing aspects of the literary focus he wished to circumvent (demonstrated by an underlying affinity with post-structuralist thought). What I want to offer here is not a wholesale dismissal of this performance studies approach, but rather a way to rescue aspects of Frith's theory in the service of understanding how certain recordings might function as a kind of autobiography. There is a hint of this possibility in Frith's admission that one of the most interesting aspects of popular culture lies in 'the shifting boundary between the "staged" and the everyday". ${ }^{43}$ Indeed, this is precisely what makes neat demarcations between real person, star persona, lyrical character, interpolated character and so on unprofitable to draw and follow. It is also what keeps audiences forever guessing and engaged. Consider, for instance, the torch song, an ode to lost love. Frith notes that classic torch singing as practised by artists such as Billie Holiday was 'a highly disciplined skill', yet one requiring attention to 'the pleasures and difficulties of interpreting feelings, atmosphere, verse'. ${ }^{44}$ When the singer is also the songwriter, this process is doubled: songwriting demands a similarly skilled negotiation of experience through reflection and creative imagination.

An example might help here. Joan Baez's torch song 'Diamonds and Rust' narrates the repercussions of a telephone conversation, tracing the spectral presence of a lover

41 John Langshaw Austin, How to Do Things with Words: The William James Lectures Delivered at Harvard University in 1955 (Oxford: Clarendon Press, 1962). See also Jonathan Culler, 'Philosophy and Literature: The Fortunes of the Performative', Poetics Today, 21 (2000), 503-19.

42 This textual focus is, of course, characteristic of Birmingham School cultural studies: see, for instance, Dick Hebdige, Subculture: The Meaning of Style (London: Routledge, 1979), and, for a critique of this paradigm, Rupa Huq, Beyond Subculture: Pop, Youth, and Identity in a Postcolonial World (Abingdon: Routledge, 2006).

43 Frith, Performing Rites, 204.

44 Ibid., 200. 
through the vagaries and non sequiturs of memory. The singer recalls that she had once given herself wholeheartedly to a young bohemian who had 'burst on the scene already a legend', a 'vagabond' who was gifted not only the Virgin Mary, but also a Roman emblem of divine love and motherly protection to boot (alluded to via Botticelli's The Birth of Venus, where the goddess is depicted nude on a scallop shell). The ingénue, in short, offers herself up as guardian, guide and lover. A contrasting section before the final stanza shifts the song's temporality and tonality simultaneously, mirroring a mind racing in non-narrative outbursts through a vista of euphoric reminiscence spun in loose, unmetrical recitative:

Now you're smiling out the window

Of that crummy hotel

Over Washington Square

Our breath comes out white clouds

Mingles and hangs in the air

Speaking strictly for me

We both could have died then and there.

A return to tonal stability arrives in tandem with the caller's indictment of nostalgia, answered by a charge of hypocrisy: 'Give me another word for it / You who are so good with words.' Clearly, this Midwestern vagabond had a keen literary eye.

The implied puzzle is not difficult to piece together. The song was written in 1974 and makes reference to events a decade earlier (when she had bought him a pair of cufflinks, half-rhymed with the 'something' he had bought her, as if neither party can quite remember or perhaps nothing was given in return); the caller is a former lover with piercing blue eyes and an aptitude for lyricism, a freewheeling drifter who frequented the folk-music haunts of Greenwich Village. It is unmistakably Bob Dylan - that 'Dada King' whose magic, Baez recounts, 'came out of a well of small gems and an inexcusable charm'. ${ }^{45}$ A rare glimpse into Baez's own abilities as a songwriter, 'Diamonds and Rust' is a song we are openly encouraged to hear in the knowledge of her relationship with Dylan during the early 1960s; it is an example of song being used to reflect on intimate personal experience. Baez tells us that some version of this conversation had in fact taken place, her writing veering in a new direction after a call in which Dylan read 'the entire lyrics to "Lily, Rosemary, and the Jack of Hearts" that he'd just finished, from a phone booth in the Midwest'. ${ }^{46}$

45 Joan Baez, Daybreak (New York: The Dial Press, 1968), 83.

46 Mike Ragogna, 'How Sweet the Sound: An Interview with Joan Baez' (18 March 2010), <https:// www.huffpost.com/entry/how-sweet-the-sound-an-in_b_320193> (accessed 3 May 2019). The lyrics of 'Lily, Rosemary, and the Jack of Hearts' were sketched during the summer of 1974 and a version was initially recorded in New York City in September of that year. Dylan famously recut a number of songs from Blood on the Tracks in December 1974 at Sound 80 studios in Minneapolis; 'Lily, Rosemary, and the Jack of Hearts' was one of these tracks. Based on the clues Baez gives us, Dylan could have been calling from Minnesota at around the time of the Sound 80 sessions, but this would mean that he had finished the lyrics several months earlier rather than recently, as implied by 
In a more recent memoir, Baez recounts meeting the young rhymester, sketching out the scenario that gave rise to the lyrics of 'Diamonds and Rust':

I first saw Bob Dylan in 1961 at Gerde's Folk City in Greenwich Village [...] He seemed very small and very young. I was older by six months, and I felt like his mother [...] The crummy hotel over Washington Square was twelve dollars a night. It had no room service, and a regular clientele of junkies, pushers, transsexuals in transition, young alcoholics, and other dubious New York street riffraff. It made me feel 'beat' and made Bob feel quite at home. I bought Bob a big black suit jacket which almost fit. He had been wary, but had also succumbed to a white shirt and - the crowning glory - a pair of cuff links. ${ }^{47}$

From that day onwards, she notes, 'It was as though we moved slowly out of the eye of the hurricane into the turbulence, the wind knocking his hand away from mine.' ${ }^{248}$ Their relationship would not weather the storm of Dylan's snowballing notoriety, famously captured in the 1967 film Don't Look Back. But much like Dylan himself in Blood on the Tracks, Baez chooses to look back through song: 'Diamonds and Rust' is a wistful lyric return to a home that no longer exists. ${ }^{49}$ Her writing and singing is classically 'allocutive' - a lover's address to another who, as Barthes puts it, 'may have shifted to the condition of a phantom'. ${ }^{50}$ Together with the work of Carole King, Carly Simon, Janis Ian and Joni Mitchell, Baez's song offered a way for a new generation of young women coming of age during the 1960s to understand their own experiences of enchantment, disillusionment, nostalgia and liberation. ${ }^{51}$

Certain scholars have begun to move away from an emphasis on theatricality and personification towards acknowledging the kind of intimate, confessional writing that Baez's song undoubtedly represents. We would miss the point, surely, if we were to hear 'Diamonds and Rust' merely as an exercise in performative duplicity. Keith Negus, for example, has questioned the precept that somehow 'truth and meaning resides in the performance persona or star image'. This position, he argues,

ignores the way that knowledge of the real author informs interpretations of the personae. There is something behind and backstage, no matter how inaccessible to the curious fan. I see no reason why we cannot retain a sense of both real author and performing persona without romantically reducing one to an expression of the other, or eradicating the real person by assuming a postmodern collapsing of the real and its representation. ${ }^{52}$

Baez's statement that 'he'd just finished'. See Clinton Heylin, Bob Dylan: Behind the Shades, The 20th Anniversary Edition (London: Faber \& Faber, 2011), 370, 381-2. Joan Baez, And a Voice to Sing With: A Memoir (New York: Simon \& Schuster, 2009), 83-5.

48 Ibid., 86.

49 See Timothy Hampton, 'Tangled Generation: Dylan, Kerouac, Petrarch, and the Poetics of Escape', Critical Inquiry, 39 (2012-13), 703-31.

50 Roland Barthes, A Lover's Discourse: Fragments, trans. Richard Howard (London: Vintage, 2002), 74.

51 Judy Kutulas, “That's the Way I've Always Heard It Should Be”: Baby Boomers, 1970s SingerSongwriters, and Romantic Relationships', Journal of American History, 97 (2010-11), 682-702. See also Sheila Whiteley, Women and Popular Music: Sexuality Identity and Subjectivity, (London: Routledge, 2000).

52 Keith Negus, 'Authorship and the Popular Song', Music and Letters, 92 (2011), 607-29 (p. 623; emphasis original). 
Rather than pursuing a sociological analysis that 'simply reverses the imbalanced account of the relationship between individual creativity and social context', Negus suggests, we might look in detail at the multitude of ways in which singers and songwriters consciously 'conflate or contest the distinctions between onstage/offstage, public/private, artist/art work, documentary/drama, and real/imaginary'. ${ }^{53}$ But I think we can go further still and do away with the clumsy and distracting concept of personification in those instances where it serves either to disenchant or needlessly to obfuscate the relationship between an author and a particular song. Indeed, Negus and Pete Astor point out that singer-songwriters have the capacity to 'negotiate the meaning of their own biographies' in lyric form - an idea that requires a far more nuanced approach to writing and performance grounded in poetics. ${ }^{54}$

What amounts to a 'widening gap' in this regard between performance studies and literary theory, Joseph Roach claims, is 'the source of a number of missed opportunities'. 55 The 'greatest loss', he writes, has been 'the diminution of the Orphic - the poetic dimension of performance in its many genres, emanating from the embodied practices that serve to express the otherwise inexpressible'. ${ }^{56}$ Many singer-songwriters align precisely with what Roach identifies as this lineage of 'popular Orphism' traceable from Homer to hip hop - a long tradition of performance attentive to song-like uses of language that could unite popular music studies with more established fields across the academy. ${ }^{57}$ As Frith was forced to admit, there is a fundamental 'continuity between poetry and song, rather than a clear division'. ${ }^{58}$ Orphic performance, Roach argues, 'unmakes and remakes mimesis by blurring the boundaries between art and life'. 59 Orphic performers thus inhabit the precarious antinomies of 'self-expression and selferasure': their merging of writing, acting and singing amounts to 'the simultaneous experience of mutually exclusive possibilities - truth and illusion, presence and absence, face and mask'. ${ }^{60}$ This idea holds the key to negotiating a rapprochement between literary studies, performance studies and musicology - fields that might see poetry pertaining to the lyre as a node through which to begin new interdisciplinary dialogues drawing together their respective strengths to overcome limitations. Performance studies and popular music studies have much to learn from scholars in English literature about poetics and poiesis, the craft of lyric writing; in turn, musicology can offer these fields new ways of exploring aspects of song frequently

\footnotetext{
53 Ibid., 614, 623.

54 Pete Astor and Keith Negus, 'More Than a Performance: Song Lyrics and the Practices of Songwriting', Popular Music Matters: Essays in Honour of Simon Frith, ed. Lee Marshall and Dave Laing (Farnham: Ashgate, 2014), 195-207 (p. 200). One of the few volumes on this subject is The Poetics of American Song Lyrics, ed. Charlotte Pence (Jackson: University Press of Mississippi, 2012), which is, however, indebted to New Criticism.

55 Joseph Roach, 'Performance: The Blunders of Orpheus', Proceedings of the Modern Language Association, 125 (2010), 1078-86 (p. 1080).

56 Ibid., 1081.

57 Ibid., 1078.

58 Frith, Performing Rites, 178.

59 Roach, 'Performance', 1081.

60 Joseph Roach, 'It', Theatre Journal, 56 (2004), 555-68 (pp. 559-60).
} 
marginalized by textual or dramatic enquiry: melody, rhythm, timbre, harmonic motion, arrangement, phrasing, recording and vocality.

For now, I want to focus on the question of autobiography by developing Roach's idea that Orphic performers blur boundaries between art and life. Arising in the wake of confessional poets such as Robert Lowell and Sylvia Plath, the singer-songwriter idiom feeds off an equivocal tension between memory and invention, self-made mask and wearer. Tracing the idiom's rhizomatic growth during the post-war era, the New York Times critic Stephen Holden brings this point to the fore:

[The singer-songwriter] fused Beat literature, confessional poetry and folk-music broadsides into a new bardic tradition based on the supposedly infinite and inexhaustible self. Spontaneous self-revelation driven by moral fervor was assumed to have elevated songwriting from a craft into an art, transforming lyrics into poetry, commentary into prophecy [...] The singer became his or her own definitive interpreter on records in which the voice, song and instrumentation merged into an artistic statement. ${ }^{61}$

The crucial theme that Holden picks up on here is that singer-songwriters were seen as their own definitive self-interpreters. A large part of the widespread suspicion surrounding autobiography as a concept revolves around a misunderstanding of this process. Writing about Joni Mitchell, for instance, Lloyd Whitesell identifies what he terms an 'autobiographical speaker' in songs such as 'Amelia' and yet offers the proviso that 'autobiographical experience tends to be aestheticized and fictionalized when cast in poetic form'. ${ }^{62}$ While useful as a caution against naivety, what this perspective neglects is that autobiography entails a process of reflection and poiesis necessarily grounded in aesthetic decisions, interpretation and fictional devices (familiar to historiographers) such as narrative, metaphor and irony. ${ }^{63}$

As Janet Gunn argues, autobiography is best seen not as the private gesture of a subject writing, but rather as a twofold act of reading in which autobiographical writers become the paradigmatic 'reader' of their own lives and selves, producing work that in turn compels active reading on the part of receivers. ${ }^{64}$ Autobiography, in short, is 'a poetics of experience' - an 'act' of making sense. ${ }^{65}$ This autobiographical compulsion, Gunn claims, involves bringing to life a displayed, public version of the self' shaped and

61 Stephen Holden, 'Dylan's Children, without the Sanctimony', New York Times, 20 November 1994, 1 and 34 (p. 34), also available at <https://www.nytimes.com/1994/11/20/arts/pop-view-dylan-schildren-without-the-sanctimony.html> (accessed 20 October 2020). See David R. Shumway, 'The Emergence of the Singer-Songwriter', The Cambridge Companion to the Singer-Songwriter, ed. Katherine Williams and Justin A. Williams (Cambridge: Cambridge University Press, 2016), 11-20. The singer-songwriter is beginning to attract a new degree of scholarly attention: see, for instance, The Singer-Songwriter in Europe: Paradigms, Politics and Place, ed. Isabelle Marc and Stuart Green (London: Routledge, 2016), and Katherine Williams and Justin A. Williams, The SingerSongwriter Handbook (New York: Bloomsbury Academic, 2017).

62 Lloyd Whitesell, The Music of Joni Mitchell (Oxford: Oxford University Press, 2008), 109, 55.

63 See, for instance, Hayden White, The Fiction of Narrative: Essays on History, Literature, and Theory, 1957-2007 (Baltimore, MD: Johns Hopkins University Press, 2010).

64 Janet Varner Gunn, Autobiography: Toward a Poetics of Experience (Philadelphia, PA: University of Pennsylvania Press, 1982).

65 Ibid., 25-8. 
interpreted by means of language'. 66 Life writing thereby amounts to a 'presencing' carrying with it a depth akin to the surface of a palimpsest:

What is presenced is a reality, always new, to which the past has contributed but which stands, as it were, in front of the autobiographer [...] something to which one is continually trying to catch up but which one can never outstrip [...] The self that comes to life is not, however, the self which, like Narcissus, grasped for its mirror-image and drowned in certainty; rather it is the self which, like Antaeus, has its life in groundedness [...] The question of the self's identity becomes a question of the self's location in a world. ${ }^{67}$

Songs, I want to suggest, can work similarly as transient and imperfect interpretations of experience shaped by the demands of language, musical performance and studio production. As such, songs afford singer-songwriters the capacity to orientate themselves in the world, in relation to other people and the past. Relying on the singing voice being heard as a classic locus of subjectivity stretching back at least as far as nineteenthcentury lieder, song epitomizes this process by which life can be enfolded into text, experience into art and performance into personal identity. ${ }^{68}$

Rather than thinking in terms of personification and performative subterfuge, then, we might move towards hearing particular songs as acts of autobiographical making what Deirdre Heddon describes as a way 'to talk out, talk back, talk otherwise'. ${ }^{69}$ When we are led to believe that something has happened, Heddon notes, our reception tends to shift 'into a different emotional register'. ${ }^{70}$ A turn towards such 'Orphic' performance goes hand in hand with scholarship that questions the notion that the author, as Foucault put it, was a 'dead man in the game of writing'. ${ }^{71}$ Seán Burke demonstrates that such assertions of the author's defacement or demise amount to a kind of ontological bad faith sparked by an epistemological upheaval in post-war linguistics that functioned to keep life and the non-academic securely at bay. ${ }^{72}$ This 'pernicious' theory of absent or obliterated authorship, Camille Paglia similarly points out, prevents us from recognizing that, 'Behind every book is a certain person with a certain history [...] outside the realm of word. ${ }^{73}$ Life, as Friedrich Nietzsche attests, is the very ground upon which philosophy grows as a personal 'confession' or 'memoir' developing from instinct, prejudice and materiality rather than a cold and impersonal drive towards

66 Ibid., 15; see also p. 9.

67 Ibid., 17, 23.

68 See Benedict Taylor and Ceri Owen, 'Subjectivity in European Song: Time, Place, and Identity', 19th-Century Music, 40 (2016-17), 185-8.

69 Deirdre Heddon, Autobiography and Performance (Basingstoke: Palgrave Macmillan, 2008), 3.

70 Ibid., 10.

71 Foucault, 'What Is an Author?', 103.

72 Seán Burke, The Death and Return of the Author: Criticism and Subjectivity in Barthes, Foucault, and Derrida, 3rd edn (Edinburgh: Edinburgh University Press, 2008). See also Jane Gallop, The Deaths of the Author: Reading and Writing in Time (Durham, NC: Duke University Press, 2011), and John Farrell, The Varieties of Authorial Intention: Literary Theory beyond the Intentional Fallacy (New York: Palgrave Macmillan, 2017).

73 Camille Paglia, Sexual Personae: Art and Decadence from Nefertiti to Emily Dickinson (London: Yale University Press, 1990), 34. 
transcendent moral knowledge. ${ }^{74}$ In Burke's words, the relationship between life and work 'is one of a ceaseless and reactive interplay' - a channel always being 'traversed in both directions' at once. ${ }^{75}$ The three case studies that follow are testament to this twoway traffic between life and lyrical craft, performance and private experience, embodiment and the imagination.

\section{Vic Chesnutt: autobiography as epitaph}

On one of the early recordings of NPR's Tiny Desk concerts in April 2009, Vic Chesnutt sits demurely wearing a bucket hat, guitar hung on a thin string around his neck. ${ }^{76}$ There is something odd about his fingers, his left hand seeming to lack the agility necessary for a guitarist; his right palm is rigid and flat against the strings, and his joints are unnaturally clenched. Although we cannot see it, he sits in a wheelchair, a quadriplegic since 1983 when he was seriously injured in a single-car accident at the age of $18 .{ }^{77}$ Chesnutt describes the event and its repercussions as follows:

I don't remember anything of it [...] I was so drunk. You know, it's quite a cliché: a stupid teenager out drunk and then I had a drunk-driving car wreck and broke my neck [...] I'm an incomplete spinal cord injury. That means that I have feeling all over my body and I can move my legs a little bit [...] my fingers don't move too good at all [but] I just figured out a way to do it, you know? It's very strange. It's hard work to do it. It's not easy. ${ }^{78}$

These physical struggles do not prevent him from performing, encouraging us (in harmony with the field of disability studies) to separate an individual's functional impairment from the collective, social problem of disability. ${ }^{79}$ As a musician, Chesnutt eventually found ways to be creative within the confines of his condition, his guitar palette limited to simple chords owing to this reduced mobility. ${ }^{80}$

The song Chesnutt begins with on NPR is 'When the Bottom Fell Out', which would become the second track of his 2009 album At the Cut. His voice is resonant and

74 Friedrich Nietzsche, Beyond Good and Evil: Prelude to a Philosophy of the Future, trans. Judith Norman (Cambridge: Cambridge University Press, 2002), 8.

75 Burke, The Death and Return of the Author, 31.

76 See <https://www.youtube.com/watch?v=a8vsSQEAGnA> (accessed 3 May 2018). National Public Radio is a non-profit media organization based in Washington DC. The Tiny Desk concert series consists of regular live performances behind the desk of the All Songs Considered host and creator Bob Boilen; these performances are then uploaded as videos to YouTube via the NPR Music channel. Well worth a watch.

77 Kristin Hersh, Don't Suck, Don't Die: Giving Up Vic Chesnutt (Austin, TX: University of Texas Press, 2015), $x$.

78 Terry Gross, 'Songs of Survival and Reflection: "At the Cut", NPR Music, 1 December 2009, <http://www.npr.org/templates/transcript/transcript.php?storyId=120978388> (accessed 10 October 2015).

79 See The Disability Studies Reader, ed. Lennard J. Davis, 5th edn (London: Routledge, 2016).

80 As Chesnutt explains: 'There was a lot more kind of odd chords and things in my songs before I broke my neck [...] physically, when I could start playing the guitar again after about a year, I realized that all I could play were these kinds of you know, G, F, C- those kind of chords. And so it was going to be - well, that's what I was going to do.' Gross, 'Songs of Survival and Reflection'. 


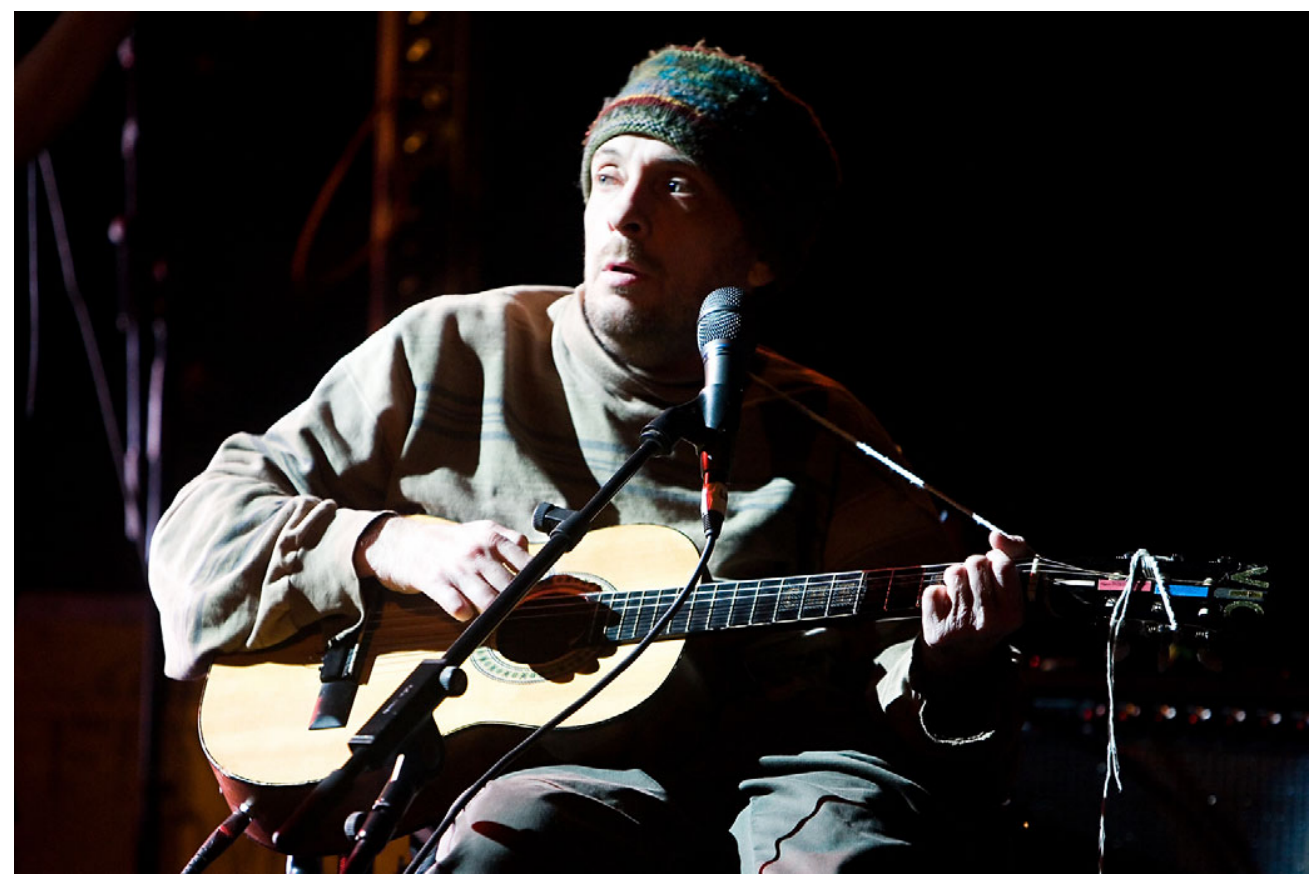

Figure 1 Vic Chesnutt performing at La Route du Rock festival (Collection Hiver) in SaintMalo, France, 23 February 2008. Reproduced by kind permission of Bertrand Degove.

measured as he intones a lyric in which the saying of having reached rock bottom is reimagined as a sudden aerial free-falling before a final plummet to the ground:

The flailing, spread-eagle

Formed an airfoil; a wing

And I gained some equilibrium

And caught myself gliding.

The song is ultimately about gratitude - for the turbulent journey, friends and the terrain towards which he is inexorably hurtling. This lyrical ' $I$ ' appears throughout Chesnutt's recordings, perhaps most noticeably on the track 'Speed Racer' from his first album, Little (1990). The chorus of this song repeats the line 'I am not a victim' before a verse in which 'divine order' and 'archaic rites' are dismissed as 'essentially crazy'. Describing the song as 'a young man's epiphany about his worldview [...] an atheist manifesto', Chesnutt is adamant, 'It's me. It's straight, you know, me as a young man. I was sitting in a college class and I had this realization. And there it is, this song.' ${ }^{81}$ As we hear him shout 'I am an atheist', it is clear that Chesnutt wishes to use the medium, as he says, to 'sing about my worldview [...] with a great amount of joy and conviction' - performing in praise of nihilism 'in the same way that Christians sing

81 Ibid. 
Gospel songs at the top of their lungs' ${ }^{82}$ Chesnutt's lyrical voice, it becomes clear, is employed to project an autobiographical reading of himself and the world around him. When he sings 'I am a coward', he entreats us to believe him.

A first-person perspective is found again in condensed form in the opening couplet of another song from At the Cut, 'Flirted with You All my Life': 'I am a man / I am self-aware.' This cogito-like assertion points not only towards deeprooted traditions of philosophical introspection, but also to placards inscribed with the phrase 'I $A M$ A MAN' carried by African American sanitation workers on strike during 1968 protests in Memphis against discrimination and dismal working conditions prompted by two gruesome and preventable fatalities. ${ }^{83}$ This tragedy caught the attention of Martin Luther King, Jr, who travelled to the city to participate in meetings and lead demonstrations against ingrained racial oppression. The day after addressing a congregation on 3 April with his visionary invocation of Moses, King was assassinated while standing on the balcony of the Lorraine Motel. ${ }^{84}$ Through these entwined references to the civil rights movement and Enlightenment philosophy, Chesnutt's lyrical voice underscores his value as a human body (to use Ralph Ellison's words) 'of flesh and bone, fiber and liquids' also in possession of a mind - emphasizing, in short, his freedom, dignity and rationality. ${ }^{85}$ The song's prelude brings these words to the fore against a sparse texture of insistent high-hat semiquavers punctuated by a slow martial drumbeat with regular contrabass interjections. At the end of the first stanza, these reiterated accompaniments meet with the addition of bright electric guitar and a Hammond organ line evoking gospel reverence - an arrangement produced in collaboration with Fugazi's Guy Picciotto, the guitarist Chad Jones and members of the ensemble Silver Mt Zion.

As we are introduced to its cycling harmonic contours (a sighing pattern in $\mathrm{F}$ consisting of I, V, ii, vi, I, V, ii, IV arranged around a series of fifths) along with the title itself, we could be forgiven for thinking that this track is a torch song:

I've flirted with you all my life

Even kissed you once or twice

[...]

When you touched a friend of mine

I thought I would lose my mind.

As Chesnutt's lyrics unfold, however, such imagery takes on new meaning through a heart-rending allegorical shift. This love song was never about a beguiling sexual

82 Gross, 'Songs of Survival and Reflection'.

83 See Michael K. Honey, Going down Jericho Road: The Memphis Strike, Martin Luther King's Last Campaign (New York: Norton, 2007).

84 King's sermon 'I See the Promised Land (3 April 1968)' is included in A Testament of Hope: The Essential Writings and Speeches of Martin Luther King, ed. James M. Washington (San Francisco, CA: Harper, 1986), 279-88.

85 Ralph Ellison, Invisible Man (London: Penguin, 2001), 3. 
partner, but rather about an unconsummated relationship with death. It is not another person with whom the singer has 'flirted' all his life, but instead the 'sweet relief' of mortality. ${ }^{86}$ Personified as the recipient of the lyric, death is sadistic yet beloved, 'cruel and constant', 'hectoring' the singer while 'decimating' those closest to him. Each reheard metaphor exposes this anguish in a different light: it is not human lips that he has already caressed without regret, but the cold embrace of suicide.

The song is rich in allusion to other poems, calling to mind Sylvia Plath's 'Lady Lazarus' ('I have done it again. / One year in every ten') with its ironic 'miracles' of curative rebirth and Keats's 'Ode to a Nightingale', in which the lyricist confesses to being 'half in love with easeful Death', having 'Call'd him soft names in many a mused rhyme'. ${ }^{87}$ But rather than addressing an other-worldly bird as Keats does, Chesnutt dares to address death itself, much like the voice in John Donne's sonnet 'Death Be Not Proud'. Indeed, 'Flirted with You All my Life' is a vocalized apostrophe to death imagined as the dark object of romantic yearning, indecision and abortive intimacy exemplifying a 'triangulated' discourse familiar within the English lyric tradition. ${ }^{88}$ The deliberately unresolved chord sequence alters the way in which we hear this appeal, casting the chorus's repeated incantation, 'Oh, Death', first in an affirmative major and then in an unexpectedly clouded and melancholic minor, creating a sense of perpetually vacillating mental states in the singer.

Indeed, the liberation that death brings is double-edged, stirring anger on the part of this figure in the final verse, occasioned by his mother's suffering:

\section{When my mom was cancer sick \\ She fought but then succumbed to it \\ But you made her beg for it \\ 'Lord Jesus, please I'm ready.'}

This bleak stanza is addressed both to death and, indirectly, to an unmerciful God offering relief, but forcing the mother to plead before surrendering even amid the most excruciating distress. The choice of syntax is defamiliarizing, highlighting a repeated sibilance and ending the first line's trochaic metre with a solitary and viscerally memorable stress: 'cancer sick' (not 'sick with cancer'). This 'sick' is spat out and rhymed simply with 'it' as part of a longer fugitive assonance between 'cancer', 'succumb' and 'Jesus', as if the concept of death so ubiquitously present in the chorus is suddenly too much to name. ${ }^{89}$ Musically, alternate lines are paired through a shared chord sequence, emulating the manner in which the text is sung: initial statement and

86 Chesnutt's use of 'sweet relief' is a nod to the Sweet Relief Musicians Fund: see <https://www. sweetrelief.org $>$ (accessed 12 October 2015).

87 Sylvia Plath, Ariel: The Restored Edition (London: Faber \& Faber, 2004), 14; Romantic Poetry: An Annotated Anthology, ed. Michael O'Neill and Charles Mohoney (Malden, MA: Blackwell, 2008), 446.

88 Culler, Theory of the Lyric, 8; see also Culler, The Pursuit of Signs: Semiotics, Literature, Deconstruction, augmented edn (Ithaca, NY: Cornell University Press, 2002).

89 Simon Jarvis, 'Why Rhyme Pleases', Thinking Verse, 1 (2011), 17-43. 
subsequent rebuke (major, resolute, unafraid), followed by the mother's suffering and a plea for deliverance (minor, fragile, despondent). Despite this passing reference to Christianity and the text's hyperbolic address, the song's meditations on death trigger no moral or spiritual dilemma; instead, they return us to Chesnutt's ardent atheism re-echoed in the ensuing song on the album, 'It Is what It Is': the futility of attempting to hedge bets 'against the looming blackness'.

The song's janiform metaphors of lust and romance take on a particular resonance in light of Chesnutt's experience. We know that he unsuccessfully attempted to take his own life on several occasions and, barely three months after At the Cut was released, finally succeeded - taking an overdose of muscle relaxants and passing away in Athens, Georgia, on Christmas Day 2009 aged only 45.90 This detail lends the song an inescapable punctum. More than simply an instantiation of poetic and performative skill, 'Flirted with You All my Life' is the result of Chesnutt's chronic existential struggle with depression - its avowed assurance ('And to this day I swear it was nice / But clearly I was not ready') overshadowed by the fact that we cannot help but hear it now as a proleptic or unintended suicide note. We thus hear Chesnutt's voice on this song in particular as an uncanny apparition, the equivocal phrase 'please I'm ready' impossible now to hear without a sense that it is not simply his mother speaking, but also Chesnutt himself. Such details, as Barthes notes, shoot out at us like an arrow, arresting and awakening our gaze, forever altering the way in which we experience a work. Considering the photograph of a condemned man, he remarks, 'I read at the same time: This will be and this has been; I observe with horror an anterior future of which death is the stake [...] what pricks me is the discovery of this equivalence. ${ }^{.11}$ In parallel with such images, the punctum throughout the song is the defeat of time by an unsettling simultaneity: 'the lacerating emphasis of the noeme ("that-has-been")' in conjunction with the thought, 'He is going to die.' 92

Chesnutt was particularly forthright about $A t$ the $\mathrm{Cut}$ in interviews, indicating the autobiographical impulse behind his frequent literary allusions from Caliban and Quasimodo to Kafka's The Metamorphosis: 'My songs are very much a kind of psychoanalysis. I am very introspective in my songs, and I am working through, always [...] It's a very personal album. It's shockingly so [...] this one felt like a memoir'. ${ }^{93}$ Asked about 'Flirted with You All my Life', he responds:

Right after my mom died was one of my last suicide attempts. It really destroyed me. My dad had died a year before, and that was the end of my whole close family, who had all

90 For newspaper obituaries, see Ben Sisario, 'Vic Chesnutt, Singer and Songwriter, is Dead at 45', New York Times, 26 December 2009, 8, also available at <https:/www.nytimes.com/2009/12/26/ arts/music/26chesnutt.html>, and Pierre Perrone, 'Vic Chesnutt', Independent, 31 December 2009, 36, also available at <https://www.independent.co.uk/news/obituaries/vic-chesnutt-singer-andsongwriter-whose-work-tackled-issues-of-mortality-1853708.html> (both accessed 12 October 2020). For a longer and more idiosyncratic tribute, see Hersh, Don't Suck, Don't Die.

91 Barthes, Camera lucida, 96 (emphasis original).

92 Ibid.

93 Scott Gordon, 'Interview: Vic Chesnutt', A.V. Club, 6 October 2009, <http://www.avclub.com/ article/vic-chesnutt-33714> (accessed 10 October 2015). 
died off within two or three years of each other: my grandpa, my grandma, my other grandma, my mom, and my dad [...] But also you see - a suicidal person, when you see somebody else die of natural causes or whatever, for me it's also a kind of wakeup call. ${ }^{94}$

It was hard for me to sing the first time I was singing it to everybody, because I was getting choked up, it was that personal. This is like going to the therapist for me. It's the song of a suicide's realization that he wants to live [...] This guy, me - I mean, it's totally personal, but you don't have to think of it that way - I'm in love with death in many ways [but] it's the realization when I say, wow, I want to live. ${ }^{95}$

The performance studies paradigm has left us ill-equipped to comprehend what Chesnutt discloses in these statements: his profound gaze into the self through lyrical writing and, equally, an adamant refusal to engage in what Timothy Hampton calls 'the arrogance of stardom'. 96 The lyrical presence that Chesnutt creates in song is at once a product of deep personal reflection on his own experience and a voice that floats free of this autobiographical 'working through', yet these two voices are inseparable twinned and confluent like the surfaces of a Möbius strip.

At the Cut is therefore neither the performance of an untethered persona nor an instantiation of direct emotional outpouring. In order to understand it, we need to turn the performance studies paradigm inside out. 'Flirted with You All my Life' is so affecting and effective precisely because it represents Chesnutt's personal experience fluently mediated through language, allusion and performance. As he makes clear, these songs not only result from musical collaboration but also play freely with references to literary works and find him, as he notes, 'lyrically [at] the top of my craft' ${ }^{97}$ To borrow words from 'It Is what It Is', such recordings provide 'curt clues' to his essence (impishly rhymed with 'planned obsolescence') and an aura of confessional honesty only as the result of poetic craftsmanship and theatrical skill. As Amanda Petrusich writes, 'When he was performing, he had the comportment of a person who had looked - and I mean really looked - into some kind of void.' ${ }^{98}$ But this should not lead us to disregard the introspective or therapeutic nature of Chesnutt's writing, the ways in which his songs exhibit undeniable traces of autobiographical agency. We give credence to Chesnutt's lyrical 'I' because through it he succeeds in overcoming the inevitable dissonance between subjectivity, singing voice, text and stage presence. Just like King's final sermon, 'Flirted with You All my Life' thus appears as an ominous prophetic revelation - not of the Promised Land, but of a broken promise. It is Chesnutt's self-examination of this hunger for life and the freedom of death that comprises the epitaph of his autobiography, an epitaph that literally (in de Man's words) gives us a 'voice-from-beyond-the-grave'. 99

94 Gross, 'Songs of Survival and Reflection'.

95 Gordon, 'Interview' (emphasis original).

96 Timothy Hampton, Bob Dylan's Poetics: How the Songs Work (New York: Zone Books, 2019), 13.

97 Josh Neas, 'Vic Chesnutt: The AD Interview', Aquarium Drunkard, 31 August 2009, <http:// www.aquariumdrunkard.com/2009/08/31/vic-chesnutt-the-ad-interview> (accessed 10 October 2015).

98 Amanda Petrusich, Foreword, in Hersh, Don't Suck, Don't Die, ix-xv (p. x).

99 De Man, 'Autobiography as De-facement', 927. 


\section{Sun Kil Moon: autobiography and the particular}

Songs can give us fragments of somebody else's reality while making that reality seem opaque, oblique and resistant to interpretation; they can convey specific details and yet still paint in broad brushstrokes. A good example would be 'Carry Me Ohio' from the 2003 album Ghosts of the Great Highway by Mark Kozelek, alias Sun Kil Moon. This song weaves together what could be an unsent or unanswered love letter with internal monologue and a numinous, repeated plea: 'Heal her soul, carry her, my angel, Ohio.' Whereas this song is more consciously elusive than concrete (though we know that Kozelek himself hails from Ohio), his more recent recordings have shifted the balance in the opposite direction, focusing on the minute details of his daily existence. The eleventh track of his 2012 album Among the Leaves, for instance, is entitled 'Track Number 8' - a tongue-in-cheek gesture during which he admits that the song 'ain't great / Will probably sequence at track number eight'. Sung in his offhand, colloquial manner and accompanied by an idiomatic classical guitar underlay, Kozelek's lyrics become a meditation on their own genesis:

These are some words I wrote down last night

I've beat 'em to death and I can't get 'em right

Songwriting's lonely; songwriting hurts

A relentless itching bedbug curse.

And yet, in spite of this declared frustration, the text itself is tightly controlled. The first, third and final lines all contain nine syllables (while the second, appropriately, doesn't get it right); the words 'night', 'right' and 'writing' form a rhyming chain, as does the interlaced sequence 'words', 'hurts' and 'curse'; and the final line's closely paired trochaic stress imitates the irksome sensation being described.

As Kozelek tell us, 'On "Track Number 8" I just hit a roadblock in the middle and decided to bring that into the theme. Songs are puzzles - you get an intro, or maybe an end, but you gotta fill in the rest.' 100 This lyrical 'I' is thus Kozelek at a distance from himself employing the craft of a seasoned songwriter to comment upon his own working methods through the medium of song. There is a doubleness at play that reveals something fundamental about the songwriting endeavour: an ostensibly realtime stream of consciousness and a hidden puppeteer creating and controlling this effect; a naturalistic voice and the intricate, literary process via which it is generated. This covert act of self-ventriloquism is put to good use on his 2014 album Benji, characterized by Pitchfork as a work of 'confrontational realism'. ${ }^{101}$ The album's 11 tracks amount to an integrated song cycle rooted in the import and simplicity of

${ }^{100}$ Laura Snapes, 'Interview: Mark Kozelek', Pitchfork, 23 May 2012, <https://pitchfork.com/features/ interview/8845-mark-kozelek> (accessed 4 May 2018).

${ }^{101}$ Ian Cohen, 'Sun Kil Moon, Benji', Pitchfork, 3 February 2014, <http://pitchfork.com/reviews/ albums/18860-sun-kil-moon-benji> (accessed 10 November 2015). 


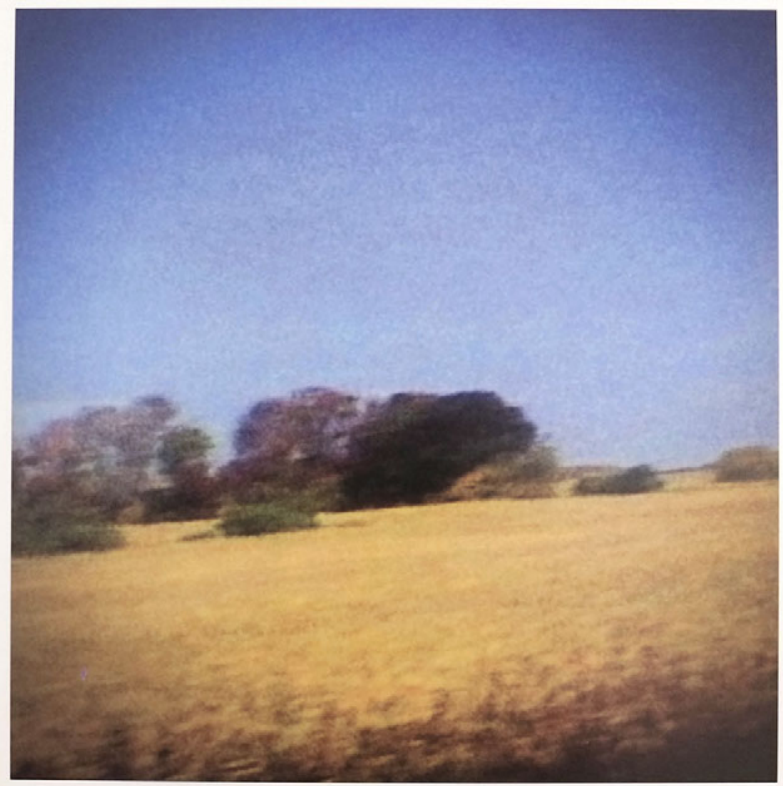

Figure 2 Front cover art of Sun Kil Moon's LP Benji (2014), Caldo Verde Records / Vinyl Films (VFR-2014-1). Author photograph. Reproduced by kind permission of Mark Kozelek.

the quotidian - their seemingly trite or clumsy lyrics employed to communicate unflinching examinations of friendship, family and personal memory. ${ }^{102}$

The opening song, 'Carissa', is an elegy recounting a 'senseless tragedy' that initiates a journey of return to Kozelek's home town and a concomitant journey of nostalgia into a nadir of childhood recollection that pervades the album. The cover artwork is a grainy photograph of a landscape taken at speed: travel both geographic and temporal permeates the songs, producing strata that appear to move at different velocities - a texture echoed in the relationship between Kozelek's free-roaming baritone and his subdued nylon-string guitar. This accompaniment is played in a deep open tuning and doubled, creating a wash of bass resonance that lends the song a feeling of warmth and gravity. Shortly after an address to the eponymous wild child, a blunt shift in lyrical voice occurs away from the intimacy of 'I/thou':

Yesterday morning I woke up to so many 330 area code calls

I called my mom back and she was in tears and asked had I spoke to my father

${ }^{102}$ For an interpretation of the song cycle as a form up to the present day, see Laura Tunbridge, The Song Cycle (Cambridge: Cambridge University Press, 2010). 
Carissa burned to death last night in a freak accident fire

In her yard in Brewster; her daughter came home from a party and found her.

Ending abruptly as if refusing to aestheticize her pain, the song (we are told) is simply a way to 'make some sense' of Carissa's death by translating her life into poetry - an apostrophic act that constitutes Carissa herself as a listening presence, summoning her into the sphere of the song as a revenant or the recipient of a letter.

Carissa J. Sampsel was indeed Kozelek's 'little second cousin' who worked as a registered nurse, was the mother of two children and died aged 35 in $2013 .{ }^{103}$ The song carries the hallmarks of documentary realism, shot through with a wounding candour inseparable from fact. Benji's third track, 'Truck Driver', continues in a similar vein, drawing a portentous link between Carissa and her grandfather:

['Truck Driver' is] about my uncle who was in critical condition from a fire accident and eventually died, about five or six years ago. I was playing the song at concerts in May. A month later, in June, my mom called me and told me that my second cousin Carissa just died the exact same way - from an aerosol can explosion [...] If you live in the country, you burn trash, and occasionally accidents happen. In my uncle's case, it was a gas can; in Carissa's, it was aerosol [...] I don't know what the meaning is but I'm compelled to write about these people, to pay tribute to them. ${ }^{104}$

Kozelek refuses to engage in extravagant rhetoric, depicting their lives all the more poignantly through sheer restraint - his guitar work conveying and diffusing an emotional burden suppressed by such stark and simple vocalization.

Through these songs we are thus thrown into unearned, almost voyeuristic intimacy with a lyrical voice that we take to be Kozelek's own. Benji, as Ian Cohen points out, is 'filled with songs that wouldn't make sense if covered by anybody else'. ${ }^{105}$ Like much of the album, 'Truck Driver' is an act of self-making dwelling on themes of family and moments of Proustian recollection, ${ }^{106}$ the song's outwardly naive language typical of Kozelek's skilful modelling of vernacular speech:

I was probably five at their home in Navarre

My cousin's friend was in the yard playing guitar

We all gathered round, listened to her play and sing

${ }^{103}$ Searching for Carissa's name online brought up several obituaries and a short article in the Canton Repository dated 20 May 2013; see <https://www.legacy.com/obituaries/name/carissa-sampselobituary?pid $=164905077>$ (accessed 12 October 2020).

${ }^{104}$ Jaan Uhelszki, 'Mark Kozelek Talks about the New Sun Kil Moon Album Benji', 31 January 2014, <http://www.caldoverderecords.com/interviewJaanKozelek.html> (accessed 10 November 2015).

105 Cohen, 'Sun Kil Moon'.

${ }^{106}$ For elucidations of these biographical moments, see Mark Kozelek, 'Song for my Father', New York Times, 14 June 2013, <http://opinionator.blogs.nytimes.com/2013/06/14/song-for-my-father>; Kozelek, 'A Love Song to Mom, from Me (and Bonnie "Prince" Billy)', New York Times, 19 July 2013, <http://opinionator.blogs.nytimes.com/2013/07/19/a-love-song-to-mom-from-me-and-bonnieprince-billy>; and Kozelek, 'The Song Remains the Same (and Kind of Blue)', New York Times, 24 January 2014, <http://opinionator.blogs.nytimes.com/2014/01/24/the-song-remains-the-sameand-kind-of-blue> (all accessed 5 November 2015). 
And I fell into a trance and knew that one day I'd do the same thing [...]

And after the funeral out there in Navarre

They all gathered round when I picked up a guitar

They fell into a trance as I sang and I played

And outside the frogs croaked and the mantises prayed.

These two stanzas mirror each other across time: the lyrical protagonist as a child spellbound by listeners gathered around a girl who sings and plays the guitar, and this figure as an adult transfixing silent mourners at a wake. Through rhyme, his guitar playing becomes a transcendent act of supplication that echoes the praying of mantises, who join a chorus of frogs as if his uncle's death had moved the very fabric of nature - or as if nature stood unremitting and indifferent to human loss.

Investigation of these particular 'biographemes' or biographical fragments, however, reveals the extent to which such childlike realism is predicated on acts of invention and imagination. ${ }^{107}$ As Kozelek recounts during an interview, these two vignettes are a primary illustration of his resourcefulness as a songwriter:

Things didn't happen exactly like that. What actually happened was, after my uncle's funeral, my mother and I were in a car accident, and an ambulance was called. The car was totaled, but we were okay. That's the beauty of songwriting. I was able to replace that memory with a better one: the memory of me playing guitar for my cousins on a separate occasion [...] The beauty of poetry is being able to express, and to alter, where it feels appropriate. ${ }^{108}$

Although it is tempting, it would be imprudent to read every aspect of Benji as if Kozelek was offering up an impulsive account of his own life. The fact that we tend to hear the album this way is the result of careful, camouflaged craft.

What Benji presents us with is a central quandary of the autobiographical endeavour: the recounting of events through words that necessarily reconfigure what is told. As Roger Luckhurst notes, whereas autobiographical discourse is meant to convey the 'unequivocal truth' it does so in a medium that 'inherently errs, its ambiguities proliferating meanings and foiling even the best of intentions'. ${ }^{109}$ Put simply, autobiography is experience mediated by language and literary form - the ensuing transformations intentionally moderated or overlooked in both production and reception. Ben Ratliff picked up on this contradiction in his New York Times review of the album: although there is 'no such thing as narrative honesty in a song', what makes Kozelek's recent work noteworthy is his graphomaniacal will 'to put the narrowness and ungainliness of daily life and

107 Barthes, Sade / Fourier / Loyola, trans. Richard Miller (London: Jonathan Cape, 1977), 9.

${ }^{108}$ Uhelszki, 'Mark Kozelek Talks'.

${ }^{109}$ Roger Luckhurst, 'Breaking the Pact: Contemporary Autobiographical Diversions', A History of English Autobiography, ed. Adam Smyth (Cambridge: Cambridge University Press, 2016), 402-16 (p. 403). 
work into his music'. ${ }^{110}$ Moore might therefore characterize these songs as illustrations of what he terms 'authenticity of expression' - something arising when an author 'succeeds in conveying the impression that his/her utterance is one of integrity, that it represents an attempt to communicate in an unmediated form with an audience'. ${ }^{111}$

Kozelek, however, purposely subverts such ideals of authenticity through recording. Performing a written text, as Christopher Ricks reminds us, alters 'the hiding-places of its power'. ${ }^{112}$ Kozelek's songs partake in the Brechtian tactics of indie - a critical and self-conscious aesthetic, as Emily Dolan notes, that depends upon deconstructing ideals of truthfulness by drawing renewed attention to the lineaments of musical mediation. ${ }^{113}$ Incorporating and extending aspects of this lo-fi attitude, Kozelek can be seen to engage in what Dolan depicts as a kind of indie sprezzatura, 'a cultivated "nonchalance"' used to conceal artistic effort and redeem sentimentality. ${ }^{114}$ Benji is successful precisely because Kozelek refuses to rely on the signifiers of expressivity made familiar by the mainstream - whether punk-like rawness, unplugged innocence, impassioned delivery or melodic grace. Instead, he employs refined classical guitar technique but assiduously strips back vocal colour and melodic contour (and, at the opening of 'Dogs', clarity and presence) to generate moments that distort the signs of heightened emotionalism while relaying undeniably emotional content. In so doing, Kozelek bares the devices of his craft, staging a critique of the confessional mode even as he adopts it. His songs speak in multiple registers at once, confusing horizons of expectation inherited from the singer-songwriter's roots amid the folk revivalism of the 1960s. ${ }^{115}$ Benji appears simultaneously naturalistic and distorted, ironic and honest, candid and contrived. If it authenticates anything, it is the old indie credo that authenticity itself is a dubious and capricious virtue always at risk of being co-opted in the pursuit of profit.

It is via such estrangement that we are compelled to reassess not only our own habitual reactions, but also certain conventions of the singer-songwriter idiom that are in danger of becoming too polished and predictable. Benji removes listeners from the realm of automatized perception, engaging - to borrow Viktor Shklovsky's words - in a kind of 'impeded, distorted speech' that trips up our listening and feeling in order to

${ }^{110}$ Ben Ratliff, 'Sun Kil Moon', New York Times, 11 February 2014, 3, also available at <https:// www.nytimes.com/2014/02/11/arts/music/albums-from-sun-kil-moon-and-robert-ellis.html> (accessed 12 October 2020).

111 Allan F. Moore, 'Authenticity as Authentication', Popular Music, 21 (2002), 209-23 (p. 214; emphasis original).

112 Christopher Ricks, Dylan's Visions of Sin (Edinburgh: Canongate, 2011), 19.

${ }^{113}$ Emily I. Dolan, ““... This Little Ukulele Tells the Truth”: Indie Pop and Kitsch Authenticity', Popular Music, 29 (2010), 457-69. See also Phil Ford, Dig: Sound and Music in Hip Culture (Oxford: Oxford University Press, 2013), and Wendy Fonarow, Empire of Dirt: The Aesthetics and Rituals of British Indie Music (Middletown, CT: Wesleyan University Press, 2006).

${ }_{114}^{114}$ Dolan, ““... This Little Ukulele Tells the Truth”, 464.

115 On this history, see Simon Frith, "The Magic That Can Set You Free”: The Ideology of Folk and the Myth of the Rock Community', Popular Music, 1 (1981), 159-68. 
make us listen and feel anew. ${ }^{116}$ Sounding both fragile and resilient, artificial and spontaneous, Kozelek's vocal timbre and diction are key to this defamiliarizing act. We hear on record not simply Mark Kozelek, but the simulated mask of 'Sun Kil Moon' Kozelek's voice typically doubled or eclipsed, awkwardly unmelodious and deliberately out of sync with itself. Sun Kil Moon albums thus place the 'auto' of autobiography under erasure, presenting Kozelek's life writing at a remove from the self - an ironic, self-protective device that allows him, paradoxically, to be self-expressive and emotionally unguarded. Intimacy results from these very distancing effects: through contrivance, we arrive at something palpably sincere.

As Ratliff attests, Benji draws its strength from playful engagement with a series of snares in which, 'One quality turns out to be related to its opposite: guilelessness leads back toward guile, dry realism toward maudlin sentimentality, narrowness toward grandiosity.' 117 But perhaps narrowness and grandiosity are not so very distant after all. Discussing his poem 'Paterson', for instance, William Carlos Williams asserts that, 'For the poet there are no ideas but in things.' 118 For Williams, the poet's business is 'not to talk in vague categories but to write particularly, as a physician works, upon a patient, upon the thing before him, in the particular to discover the universal'. ${ }^{119}$ This is precisely what Kozelek does, his next Sun Kil Moon album tellingly entitled Universal Themes. Much like Williams, he admits that, 'What I'm surrounded by is a good place to start in any song [...] when I write lyrics something real comes out of me. I don't know any other way to do it.' ${ }^{120}$ The songs on Benji have a wide compass as a result of this autobiographical specificity. Kozelek's lyrical 'I' is used to dissect and ground the self in an immediate environment, even as it echoes beyond these narrow confines. The products of judiciously veiled invention, Kozelek's recordings are windows onto an attempt to recover time through the particular. His songs renounce aesthetic autonomy as gleanings from a life lived in the knowledge of being transformed into art.

\section{Anohni: autobiography as testimony}

The lyrical voice can encode more than one perspective, being at once both revelation and role play, self and other. The title of the 2005 album I Am a Bird Now by Antony and the Johnsons implies that such a transformation has taken place. The vocal lines soar, quivering but calm like Percy Bysshe Shelley's bird that pours out its heart 'In profuse strains of unpremeditated art'. Indeed, the song 'Bird Gerhl' shares its theme with 'To a Skylark': the aspiration to become one with the lyric's ethereal addressee, the voice of the poet aspiring to mimic the lark that sings something more than earthly music. And yet the deliberately awkward, even ugly onomatopoeic spelling signals that

\footnotetext{
${ }^{116}$ Viktor Shklovsky, Theory of Prose, trans. Benjamin Sher (Normal, IL: Dalkey Archive Press, 1990), 13 (emphasis original).

117 Ratliff, 'Sun Kil Moon'.

118 William Carlos Williams, The Autobiography of William Carlos Williams (New York: New Directions, 1967), 390.

119 Ibid.

${ }^{120}$ Uhelszki, 'Mark Kozelek Talks'.
} 
this becoming is couched in lacerating self-awareness and linguistic distance from an ideal, the pronoun 'her' broken but secreted within its form. On the recording, this vocal presence hesitates, managing only a faint 'I am' during the song's soft prelude. After 25 seconds the voice begins to assert itself more urgently, restating the phrase 'I am bird girl' like a mantra as the piano accompaniment moves through a chord sequence involving a deceptive cadence coinciding with the word 'now'. We are told by this lyrical voice that she has been 'searching for my wings some time', this fledgling seeming to take flight only as the song's texture swells with the addition of a string quartet, bass and percussion. The enigma the song presents us with is this breathy, sibilant voice described by one critic as 'angelic in its androgyny'. ${ }^{121}$ Who is this queerly mellifluous 'gerhl' and why the emphasis on 'now'?

An answer can be found on the album's third track, 'For Today I Am a Boy', in which the lyricist, borne back imaginatively into childhood, looks forward to that day when this former boy-self will 'grow up' to become a 'beautiful woman'. In the present of the song, all this protagonist can do is reaffirm their desire in the knowledge of temporary confinement - echoed by a synthetic choir of her/his own voice(s) redoubled and already inhabiting an ambiguously gendered space more female than male, less countertenor than contralto. The song, in other words, performatively enacts the very identity it anticipates: the voice singing of confinement becomes the voice it aspires to be. I Am a Bird Now hence establishes for listeners what Philippe Lejeune refers to as an 'autobiographical pact'. ${ }^{122}$ The transgender voice we hear invites us to witness the singer as a transgender subject - an identity indicated by a doubleness of name (then Antony, now Anohni) that Lejeune, writing of literary pseudonyms, might refer to as the symptom of a 'second birth'. ${ }^{123}$

The name Anohni, however, is more than a mere nom de plume, troubling the idea of transition. Anohni, whose work emerged out of New York's downtown queer/punk experimental theatre hub of the 1980s, describes her identity as follows:

I've never been a man and I've always said I'm not a man, but I've been living with this male name and I was just humoring people calling me 'he', and I was a little ashamed of asking for anything more than that. So I finally got the courage to say 'I want you to address me as she because I want you to honor my spirit. I'm a transgender person that wants to be recognized for my feminine essence and aspect.' ${ }^{124}$

${ }^{121}$ Colin Carman, 'Metamorphosis of an Indie Rock Star: Anohni's "Hopelessness"', Gay and Lesbian Review Worldwide, 23/5 (2016), 50. On queer vocality, see Freya Jarman-Ivens, Queer Voices: Technologies, Vocalities, and the Musical Flaw (Basingstoke: Palgrave Macmillan, 2011).

122 Philippe Lejeune, On Autobiography, trans. Katherine Leary (Minneapolis, MN: University of Minnesota Press, 1989), 3.

${ }^{123}$ Ibid., 12.

${ }^{124}$ Emilie Friedlander, 'Anohni's Eyes Wide Open Campaign', Thump, 21 April 2016, <https:// thump.vice.com/en_us/article/53ay8b/anohni-hopelessness-hudson-mohawke-oneohtrix-pointnever-interview> (accessed 17 April 2018). On the troubled intersection of feminism and trans identity, see Lori Watson, 'The Woman Question', Transgender Studies Quarterly, 3/1-2 (2016), 246-53, and The Transgender Studies Reader, ed. Susan Stryker and Stephen Whittle (New York: Routledge, 2006). 
Related themes appear throughout Antony and the Johnsons' catalogue - a kind of confessional collage written, as Anohni puts it, from an 'interior safe place' that concentrated on 'healing myself and sharing that self-help with people'. ${ }^{125}$

To focus on an increase in trans visibility here, however, would be to do an injustice to Anohni's more recent songwriting and political advocacy. Reproving 'myopic, selfserving communities' of single-issue activists, she has repeatedly asserted that we face an array of far more immediately pressing issues as citizens and as a species - narrow identity politics neglecting to 'connect the dots' between these co-dependent issues. ${ }^{126}$ The parallel she chooses to draw is significant:

It's like AIDS. There's this underlying systemic immune deficiency that enables the outbreak of any number of what they used to call 'opportunist infections'. I think of things like the subjugation of women, drone warfare, neoliberal capitalism, Christian and Islamic fundamentalism, racism, police brutality, mass incarceration, massive wealth disparity, corporate sovereignty, the weapons industry, the fossil fuel industry, the chemical and pharmaceutical industries, population explosion, factory farming, and the destruction of wilderness as opportunist infections. ${ }^{127}$

'It's not wrong to fight for justice for your special-interest group,' she adds, 'but we've been deceived into thinking that's the endgame.' 128

For Anohni, the endgame proper is to heal a profound sickness at the heart of postmodern existence indicated by global climate devastation, digital surveillance and US military intervention in the Middle East. These interlaced concerns coalesce on her 2016 album Hopelessness. Rather than producing a cycle of agonistic songs in the folk protest tradition, Anohni fuses the personal and the political in a gesture reminiscent of second-wave feminism. The radical gesture behind such determined coupling of the private and the social during the late 1960s and 1970s, Heddon notes, 'was the insistence that the personal was never only personal since it was always structural and relational': work in this vein accordingly aims to illuminate 'the relationship between the personal and the political'. ${ }^{129}$ This is precisely what Hopelessness sets out to achieve, laying bare personal testimony to shed light on what appears to be an unassailable ecological and sociopolitical infirmity. As Anohni states, the album involves 'trying to look inward just

\footnotetext{
125 Friedlander, 'Anohni’s Eyes Wide Open Campaign'.

126 Jason Lamphier, 'Anohni Talks Protest-Minded Pop, Identity Politics, Oscar Boycott', Rolling Stone, 10 May 2016, <https://www.rollingstone.com/music/news/anohni-talks-protest-minded-popidentity-politics-oscar-boycott-20160510>; Brandon Stosuy, 'Anohni on Art, Corporations, and the Music Industry', Creative Independent, 10 October 2016, <https://thecreativeindependent.com/ people/anohni-on-art-corporations-and-the-music-industry> (both accessed 10 April 2018).

127 Stosuy, 'Anohni on Art'. This vision of a malign system echoes a key aspect of 1960s discourse: see Howard Brick, Age of Contradiction: American Thought and Culture in the 1960s (Ithaca, NY: Cornell University Press, 1998). Anohni also works as a visual artist: see Anohni: My Truth, James Elaine, Peter Hujar, Kazuo Ohno, ed. Friedrich Meschede (London: Koenig Books, 2017).

${ }^{128}$ Ben Beaumont-Thomas, 'Anohni, the Artist Once Known as Antony Hegarty, on Life beyond the Johnsons', The Guardian, 9 April 2016, <https://www.theguardian.com/music/2016/apr/09/transsinger-anohni-new-album-hopelessness> (accessed 10 April 2018).

${ }^{129}$ Heddon, Autobiography and Performance, 161-2 (emphasis original).
} 
as intensely' as she is looking outwards. ${ }^{130}$ Hopelessness breaks away from what she has come to view as a certain passivity or indulgence in her previous work, raising her voice as 'the antidote to a sense of powerlessness'. ${ }^{131}$ This combative stance is coupled with a new sonic palette (courtesy of Ross Birchard aka Hudson Mohawke and Daniel Lopatin aka Oneohtrix Point Never) steeped in a nostalgic and slickly produced fusion of anthemic R \& B, ambient electronica and EDM - a soundscape that Anohni describes as both a 'Trojan Horse' and 'foil' to help spread her message, as well as an example of how 'expressions of anger [can be] sublimated into something beautiful'. ${ }^{132}$

The second song on the album, ' 4 Degrees', could easily be read as an instantiation of dark irony. The phrase 'It's only 4 degrees!' is restated eight times before the lyrical voice tells us of their desire to see animals 'burn', cry out for water and 'die in the trees'. The setting - a heavy, syncopated, synth-suffused beat - reads as a merciless satire of climate sceptics, corporate power, apathetic consumers and states unwilling to reduce carbon emissions, revelling in an acerbic dissonance between the euphoric, escapist vibe of the track (in which scansion of the word 'mammals' is incorrect, as if detailed attention to such beings was similarly unimportant) and the grim realities of a rapidly warming planet. Anohni, however, has cautioned against a reading that would exempt her from critique. Indeed, we begin to notice her presence in the lyrics, particularly in the striking lines, 'I want to burn the sky / I want to burn the breeze.' The motivation behind the song, she notes, was to articulate 'not my ideal vision of how I wanted to perceive my relationship with nature', but something more disconcerting - giving voice 'to the narrative that underscored the reality of my behaviour rather than of my intention'. ${ }^{133}$ The real dissonance on ' 4 Degrees' is thus a discord between the enjoyment of first-world comforts bolstered by a fossil-fuel-rich lifestyle and an ignorant, puerile or sentimentalized vision of the natural world (with 'all those tiny creatures' in Africa), a world this lifestyle will ultimately destroy. Anohni has described this lyrical voice as the utterance of her body: articulating these actions through song results in the oddly disengaged or split vocal presence, at once the voice of chart pop and of the Anthropocene; of cataclysm, consumerism and individual subjectivity.

The 'I' of ' 4 Degrees' is simultaneously Anohni and us, a lyrical illustration of collective hypocrisy and denial. The album's opening track, 'Drone Bomb Me', presents us with a similar confluence. Recalling the visceral tone of Harold Pinter's laconic poem 'American Football' condemning the Gulf War, it begins: ${ }^{134}$

${ }^{130}$ Lamphier, 'Anohni Talks Protest-Minded Pop'.

${ }^{131}$ Kelly McEvers, 'Anohni's "Hopelessness" and the Power of Speaking Out', NPR Music, 23 May 2016, <https://www.npr.org/templates/transcript/transcript.php?storyId=477967248> (accessed 10 April 2018).

132 Friedlander, 'Anohni’s Eyes Wide Open Campaign'; Brandon Stosuy, 'Anohni Finds Hope in Hopelessness', Pitchfork, 14 April 2016, <https://pitchfork.com/features/interview/9872anohni-finds-hope-in-hopelessness> (accessed 10 April 2018).

133 Jon Pareles, 'Embracing a New Name, and Sound', New York Times, 24 April 2016, 17, also available at <https://www.nytimes.com/2016/04/24/arts/music/anohni-embracing-a-new-name-and-sound. html> (accessed 12 October 2020); McEvers, 'Anohni's "Hopelessness"'.

${ }^{134}$ Harold Pinter, Various Voices: Sixty Years of Prose, Poetry, Politics, 1948-2008 (London: Faber \& Faber, 2009), 221. 


\author{
Drone bomb me \\ Blow me from the mountains \\ And into the sea \\ Blow me from the side of the mountain \\ Blow my head off \\ Explode my crystal guts \\ Lay my purple on the grass.
}

The most straightforward reading would be that this ' $m e$ ' is a ventriloquized would-be victim of US airstrikes in north-west Pakistan - a bombing campaign that, in a report published in 2013, Amnesty International states 'may amount in some cases to extrajudicial executions or war crimes and other violations of international humanitarian law'. ${ }^{135}$ Noting that her 'skill set is dreaming and shape-shifting', Anohni sees herself singing 'from the point of view of a seven-year-old girl whose mom and dad and brother were killed by a drone bomb' ${ }^{136}$ Given that this figure, addressing a pilot, begs to be 'the one that you choose tonight', Anohni has called attention to an unnervingly eroticized undertone, an aura compounded by the imminent (we might say predatory or rape-like) act of martial violence.

But the song has yet another layer. The crux seems to come with an interjected line (the first word spoken rather than sung), 'Afterall, I'm partly to blame.' Rereading the song in this light opens up an alternative possibility: the lyrical voice has been not only that of the victim but also that of the perpetrator. In short, we are listening to the vocalization of guilt - the voice of Anohni willing a figurative devastation upon herself as an act of expiatory compassion. The key line 'I'm not so innocent' suddenly takes on a double meaning and begins to refer more to a Western subject than to an orientalized other. Indeed, she emphasizes that as taxpayers, voters and citizens, we are all blameworthy: 'The virulence is deep within us. Those are our systems. And we did make these decisions. And we are paying for them [...] It's our collective consciousness.' ${ }^{137}$ Anticipating the track 'Crisis' with its insistent repetitions of contrition for geopolitical sin, the song is polyphonic, weaving the voice of suffering seamlessly with the voices of violation, regret and atonement.

What we hear throughout Hopelessness is Anohni's presence arbitrated by a series of masks that, through a kind of mirroring, are used to reflect back (upon) the self and (upon) society more broadly. This process is anticipated by the album's cover art, a black-and-white image in which a mask-like portrait of the model Liya Kebede is overlaid on Anohni's face - the composite illustrating a doubleness in which Anohni is both concealed (behind a female face) and revealed (as a woman). Analogous moments occur in live performance and the video for 'Drone Bomb Me' featuring Naomi

${ }^{135}$ Amnesty International, 'Will I Be Next?' US Drone Strikes in Pakistan (London: Amnesty International Publications, 2013), 56. See also Drone Wars: Transforming Conflict, Law, and Policy, ed. Peter L. Bergen and Daniel Rothenberg (New York: Cambridge University Press, 2015).

${ }_{137}^{136}$ Friedlander, 'Anohni's Eyes Wide Open Campaign'.

137 Stosuy, 'Anohni Finds Hope' (emphasis original). 


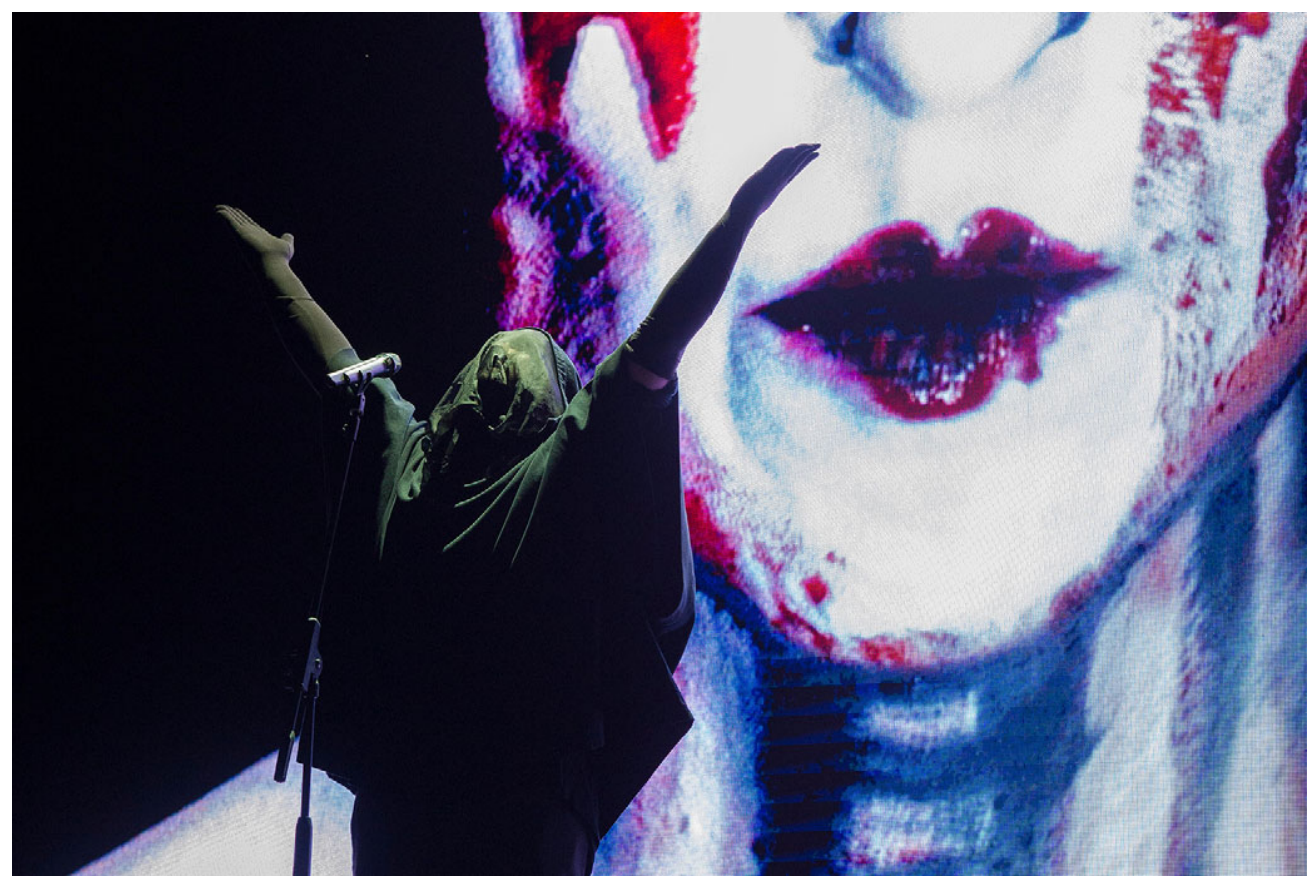

Figure 3 Anohni performing material from Hopelessness at Flowers Festival in Turin, Italy, 12 July 2016. Credit: Black Mail Press / Stefano Guidi / Lasciafare / Alamy. Used with permission.

Campbell - gestures of racial surrogation that have not escaped criticism. ${ }^{138}$ For Anohni, this channelling is a means to make her work speak as an 'oracle', separating her voice and physical form to open up a space beyond 'the local identity politic' of her own body. ${ }^{139}$ We can, however, see this masquerade as an act of autobiographical making, a form of public display that establishes an intimate correlation between lyrical writing, voice and introspection. As Hua Hsu points out, Hopelessness is no less vulnerable than her previous records', its fragility no longer situated 'between soul mates but between citizen and state'. ${ }^{140}$ There is a utopian potential in this form of subjective confession: as Heddon argues, performances that 'represent the already lived [...] beckon us towards, urge us to imagine or compel us to create the yet to be lived' ${ }^{141}$ Without the fiduciary grounding of autobiography - our trust in the songwriter's sincerity, however mediated by imagination - such work would not generate the same political and emotional impact. Anohni's lyrical and performative prosopopoeia

\footnotetext{
138 See Amanda Williams, 'How Woke Is Anohni?', Mel, 2 September 2016, <https://melmagazine. com/how-woke-is-anohni-45a648b686c4> (accessed 28 April 2018).

${ }^{139}$ Friedlander, 'Anohni's Eyes Wide Open Campaign'.

${ }^{140}$ Hua Hsu, 'Cruel Optimism', New Yorker, 2 May 2016, 78, also available at <https://www. newyorker.com/magazine/2016/05/02/hopelessness-by-anohni> (accessed 12 October 2020).

${ }^{141}$ Heddon, Autobiography and Performance, 20.
} 
is in fact a gesture of exposure, a mapping of self onto the collective that emphasizes the atomized individual's role in making up this larger body politic. Her voice is always reaching beyond itself into a landscape of possibility, fascinated with the self's location in a world of unremitting crisis.

\section{Art and artifice}

\section{[...] I feel I understand}

Existence, or at least a minute part

Of my existence, only through my art.

$$
\text { (John Shade, in Nabokov's Pale Fire) })^{142}
$$

The world was being hoaxed by a disciplined melancholy [...] the whole enterprise of art was a calculated display of suffering.

\section{(Leonard Cohen, The Favourite Game) ${ }^{143}$}

In his début novel, The Favourite Game, Leonard Cohen pins down a paradox central to the poet's and, by extension, the singer-songwriter's art: what we receive as sincere, impulsive emotion is the result of ingenuity and artistic discipline. In other words, poems and songs that appear to be authentically expressive in fact rely on technical dexterity and acts of careful calculation. Such material is therefore never directly revelatory - the illusion of directness itself a result of the singer-songwriter's craft in which personal experience is deferred like a knight's move through poetic language, genre, dramaturgy and the imagination. The singer-songwriter is thus caught in a perpetual oscillation between divulgence and masquerade, melancholy and discipline, experience and reckoning. In consequence, Ricks argues that it would be unwise to read songs in relation to their authors: 'The impersonality that is one of art's strengths is a feat, and the artist has to exercise imagination to achieve it. ${ }^{144}$ According to Ricks, any attempt to 'biographize' Bob Dylan's work is a misguided endeavour as, 'His life is his business; his art is something else.' ${ }^{145}$ Ricks goes as far as to offer us a methodological doctrine: 'Don't break works of art back down into the biographical contingencies that contributed to bringing them into being but that are not their being [...] they lead their own lives.' 146 The elucidation of song, he contends, leads not to the certitudes of biographical fact, but towards the inventive and autonomous pleasures of an 'artistic accomplishment' ${ }^{147}$

\footnotetext{
142 Vladimir Nabokov, Pale Fire (London: Penguin, 2016), 59.

143 Leonard Cohen, The Favourite Game (London: Blue Door, 2009), 120.

${ }_{144}$ Ricks, Dylan's Visions of Sin, 192.

145 Ibid., 149 (emphasis original).

146 Ibid., 192.

${ }^{147}$ Ibid., 68. Ricks does not dismiss the realm of biography entirely, admitting that 'there will sometimes be the special occasion [...] when we don't mishear a particular Dylan song if we bring it home to him and to the events of his life' - the exceptional case in question being 'Day of the Locusts' from New Morning.
} 
Much scholarship toes this line. In his close reading of Dylan's Blood on the Tracks, for example, Timothy Hampton admits the presence of autobiographical moments but maintains that, 'To read the album biographically and literally [...] makes no more sense than to read $O n$ the Road as if Sal Paradise were only Jack Kerouac. ${ }^{148}$ In short, 'Poetic echo trumps biography.' ${ }^{149}$ The problem is that Dylan has told us, 'The stuff I write does come from an autobiographical place.' ${ }^{150}$ We know that 'Dylan' on record or in performance is something other than Dylan himself, and yet he plays with a polyphony of voices in which listeners and fans are encouraged to catch glimpses of a man behind this mise en abime of masks. Missing from the 'impersonalist' approach that Ricks and others advocate is a full consideration of how the awareness of a singer's life experience - however partial and mediated it might be - not only is able to enrich our listening, but also is often inescapable or, as I have been arguing here, intentionally cultivated as an autobiographical practice.

As Michael Coyle and Debra Cohen note, Blonde on Blonde - its acronym BoB - is best seen as one of Dylan's convoluted self-portraits. ${ }^{151}$ The value of a track such as 'Visions of Johanna' lies neither in hard realism nor in dramatic abstraction, but rather in a carefully wrought process of self-scrutiny that allows Dylan to engage in what Allen Ginsberg describes, during an essay on Jack Kerouac's Visions of Cody, as 'the sacramentalization of everyday reality'. ${ }^{152}$ Just as the novel that Ginsberg discusses, as a roman- $\dot{a}-c l e f$, uses a literary device to equate Kerouac with the protagonist Jack Duluoz (and, for that matter, Sal Paradise), so material in the singer-songwriter idiom achieves its emotional depth and resonance by striving to unite the disparate voices of author, performer and lyrical 'I'. When reconciled in this way, as Vladimir Nabokov's John Shade implies, art and poetic artifice can offer up rare insights.

Why, then, is there such entrenched resistance to autobiography? We have seen that one approach, which I call the performance studies paradigm, is traceable from Auslander, Frith and Moore back to Cone - an approach that shares its recourse to performativity with post-structuralism. But Ricks presents us with a different branch relating to the so-called 'intentional fallacy', the belief that what a poet says about their work or the meaning of an image is irrelevant to the practice of criticism. In 1946, William Wimsatt and Monroe Beardsley claimed (with reference to T. S. Eliot) that 'the true and objective way of criticism' necessitates a rejection of 'biographical or genetic inquiry' and its romantic corollaries: proper enquiries, they conclude, 'are not settled by consulting the oracle'. ${ }^{153}$ It is no coincidence that Eliot is referred to in this

${ }_{148}$ Hampton, 'Tangled Generation', 715.

$149 \mathrm{Ibid}$., 721. For an extended discussion, see Hampton, Bob Dylan's Poetics, in which he specifies that 'our attention should be on the songs' rather than on Dylan himself (p. 23).

${ }^{150}$ Bob Dylan, Chronicles: Volume One (New York: Simon \& Schuster, 2004), 199.

${ }^{151}$ Michael Coyle and Debra Rae Cohen, 'Blonde on Blonde (1966)', The Cambridge Companion to Bob Dylan, ed. Kevin J. H. Dettmar (Cambridge: Cambridge University Press, 2009), 143-9.

152 Allen Ginsberg, 'The Visions of the Great Rememberer', in Jack Kerouac, Visions of Cody (London: Penguin, 2012), 1-10 (p. 4).

153 William Kurt Wimsatt, Jr, and Monroe C. Beardsley, 'The Intentional Fallacy', Sewanee Review, 54 (1946), 468-88 (pp. 486-7). 
essay. If we trace the roots of both the intentional fallacy and what I am calling the impersonalist approach to popular song, we find the blueprints for an aesthetics of literary modernism. Eliot, of course, proclaimed in 1919 in The Egoist that,

The more perfect the artist, the more completely separate in him will be the man who suffers and the mind which creates; the more perfectly will the mind digest and transmute the passions which are its material [...] the poet has, not a 'personality' to express, but a particular medium, which is only a medium and not a personality, in which impressions and experiences combine in peculiar and unexpected ways. Impressions and experiences which are important for the man may take no place in the poetry, and those which become important in the poetry may play quite a negligible part in the man, the personality [...] Poetry is not a turning loose of emotion, but an escape from emotion; it is not the expression of personality, but an escape from personality. ${ }^{154}$

Here, the poet is not someone recounting events, but a catalyst giving life to complex and concentrated forms of poetic significance. What matters is the 'artistic process', which entails 'a continual self-sacrifice, a continual extinction of personality'. ${ }^{155}$ In consequence, Eliot claims, 'honest criticism and sensitive appreciation' should be 'directed not upon the poet but upon the poetry' - instituting the formalist mantra of New Criticism. ${ }^{156}$ This is the tradition Frith was seeking to oppose.

If we read between the lines of this celebrated essay in light of John Carey's suggestion that modernist ideals were predicated on a contempt for mass literacy, however, the values of 'sensitive appreciation' and impersonality reveal themselves to be a philosophical bulwark against what Eliot chooses to depict as 'the confused cries of the newspaper critics' and 'the susurrus of popular repetition that follows'. ${ }^{157}$ Ushering the (auto)biographical - which appears to stray perilously close to the frivolous murmurings of mass culture - out of literature and literary criticism became a way of establishing a hierarchy of taste and the price of admission to the sphere of an intellectual elite. According to writers such as Eliot and José Ortega y Gasset, Carey shows, 'It was the dogged literalism of the masses that unfitted them for the appreciation of art, and banished them from the higher aesthetic reaches.' ${ }^{\prime 58}$ Fascinated by newsprint and cheap cameras, the mass population's failure was this obdurate attachment to facts, realism and human interest. In an 1891 essay prefiguring aspects of this trope, Oscar Wilde conveyed a similar critique of the unwelcome 'tyranny' of popular journalism. ${ }^{159}$ For obvious reasons, Wilde felt that 'the private lives of men and women

${ }^{154}$ T. S. Eliot, 'Tradition and the Individual Talent - II', The Egoist, 6 (1919), 72-3. On this subject, see Maud Ellmann, The Poetics of Impersonality: T. S. Eliot and Ezra Pound (Edinburgh: Edinburgh University Press, 2013).

155 Eliot, 'Tradition and the Individual Talent - II', 72; Eliot, 'Tradition and the Individual Talent [- I]', The Egoist, 6 (1919), 54-5 (p. 55).

${ }^{156}$ Eliot, 'Tradition and the Individual Talent - II', 72.

157 Ibid.

158 John Carey, The Intellectuals and the Masses: Pride and Prejudice among the Literary Intelligentsia, 1880-1939 (London: Faber \& Faber, 1992), 31. See also Andreas Huyssen, After the Great Divide: Modernism, Mass Culture and Postmodernism (Basingstoke: Macmillan, 1988).

159 Oscar Wilde, 'The Soul of Man under Socialism', Fortnightly Review, 49/340 (1891), 292-319 (p. 309). See Rochelle Rives, Modernist Impersonalities: Affect, Authority, and the Subject (New York: 
should not be told to the public', especially in the 'unhealthy conditions' brought about by capitalist demand 'to supply the public with what the public wants, and to compete with other journalists in making that supply as full and satisfying to the gross popular appetite as possible'. ${ }^{160}$ Carey sees modernist experimentation and the deliberate opacity of post-structuralist theory as twin reactions to this flourishing of consumer culture in the twentieth century - the latter establishing a self-conscious intellectual 'aristocracy' that situated itself in opposition to the new mass audience for television during the 1960s. ${ }^{161}$

We are still labouring under the shadows of this Apollonian mentality. ${ }^{162}$ Indeed, it is tempting to see impersonalist readings such as that of Ricks as a compensatory gesture for the embarrassing persistence of the very journalistic proclivity and popular susurrus that Eliot mentions, transferred onto present-day celebrities such as Dylan. There is a curious irony in popular song criticism being haunted by this spectre of modernism - an aesthetic founded upon an elitist contempt for popular culture and its troublesome imbrications with life. This ghostly presence goes some way towards explaining the gendered prevalence of an enigmatic self-portraitist like Dylan over and above a figure such as Joni Mitchell, with her more unapologetically personal repertoire. What appears to be in jeopardy in such cases is the purity of the aesthetic - the danger of content overshadowing form. But we have seen that autobiographical work presents a far more complex and compelling vision than this. Even though, as Tim Dolin puts it, lyric poems represent 'experience intensified rhythmically, phonetically, figurally', we should not forget that such writing can also be an act of self-reading. ${ }^{163}$ As Gunn suggests, autobiography exists as a kind of synecdoche, a relationship of fragment to whole, past to present, surface to apparently inaccessible depth. ${ }^{164}$ Although relevant for figures such as David Bowie or Nicki Minaj, the persona paradigm fails to account for this relationship. It would seem that to be serious scholars, we must focus attention on interpretations that do not stray too far 'beyond the text', ${ }^{165}$ setting aside (or merely leaving to mass media speculation) the intimate, human and self-revelatory aspects of song - those very features that we perhaps value most in our private experiences of listening.

Autobiography, as Burke reminds us, unavoidably entails 'a hiatus, both spatiotemporal and ontological' between the writing self and what is written. ${ }^{166}$ Put

Palgrave Macmillan, 2012), 28-33. Rives draws attention to Wyndham Lewis, whose vision of impersonality was predicated on a 'feverish distrust of democratic ideals and their grounding in mass media' (p. 1). Such themes are explored at greater length in Zeev Sternhell with Mario Sznajder and Maia Asheri, The Birth of Fascist Ideology: From Cultural Rebellion to Political Revolution, trans. David Maisel (Princeton, NJ: Princeton University Press, 1994).

160 Wilde, 'The Soul of Man', 310. On this topic, see also Ross Cole, 'Notes on Troubling "The Popular", Popular Music, 37 (2018), 392-414.

161 Carey, The Intellectuals and the Masses, 214-16.

162 See Paglia, Sexual Personae, 12.

163 Tim Dolin, 'Life-Lyrics: Autobiography, Poetic Form, and Personal Loss in Hardy's Moments of Vision', Victorian Poetry, 50 (2012), 1-19 (p. 5).

${ }_{164}^{164}$ Gunn, Autobiography, 10.

165 Moore, Song Means, 327.

${ }^{166}$ Burke, The Death and Return of the Author, 53. 
differently, reflecting on the self requires a certain distance from the self - a bifurcation or othering without which autobiography would be impossible. This paradoxical split, as Burke argues, 'is the first condition of articulating the self': the subject 'is not a communicable given until approached as an object external to itself, until an author cultivates towards his or her personality the detachment of a reader, a covert and careful interpreter of experience'. ${ }^{167}$ Hence, to subvert Eliot's reasoning, impersonality 'does not subvert so much as serve the personal, the self-revelatory, the autobiographical'. ${ }^{168}$ In order to create songs (by making use of rhyme, assonance, metrical stress, metaphor, stanzaic form, intertextual allusion, melodic contour, studio technology and so on), songwriters must be able to detach themselves from their personal experience. Performance - as what Richard Schechner has termed 'restored' or 'twice-behaved' behaviour - entails a similar rift in the performing subject. ${ }^{169}$ Yet this fact should not distract us from the intricate activities of poiesis and self-interpretation concealed behind the fascination of the stage or record. Breathing life into a lyrical ' $I$ ', singers present us with a read and rehearsed version of themselves - if successful, one that we take to be sincere. The art of the singer-songwriter aims at the erasure of this inevitable artifice in the service of verisimilitude.

As we have seen in relation to Vic Chesnutt, Sun Kil Moon and Anohni, much work in the singer-songwriter idiom is predicated on the cultivation of a hard-won consonance between author and lyrical voice - a likeness that results in moments of afflictive realism despite or rather due to the creative resistances offered up by language, performance and prosopopoeia. In our haste to acknowledge that song is an illusory, imaginative art in which the contours of expression are always being redirected and recast through the mediations of performance, we risk overlooking the obvious: that what Eliot refers to as the 'artistic process' can incorporate a close reading of the self and the world this subject inhabits. Indeed, a poetics of song should lead us towards the same quandary that inspired a young Stephen Daedalus (in an early draft of $A$ Portrait of the Artist as a Young Man) 'to establish the relations which must subsist between the literary image, the work of art itself, and that energy which had imagined and fashioned it, that centre of conscious, re-acting, particular life, the artist'. ${ }^{170}$ Although, as Maud Ellmann points out, Joyce later mocked autobiographical writing, the modernist abnegation of self, much like the death of the author, is built upon a disingenuous foundation: in Eliot and Ezra Pound, this self always 'haunts the very grammar of its ostracism'. ${ }^{171}$ Such paeans for authorial impersonality or erasure reinscribe the very personhood they dismiss, providing a refuge for the darker and more disquieting political undercurrents of the modernist project. A better way to look at the work of

167 Ibid., 220-1.

168 Ibid., 221 (emphasis added).

${ }^{169}$ Richard Schechner, Between Theater and Anthropology (Philadelphia, PA: University of Pennsylvania Press, 1985), 51-2.

170 James Joyce, Stephen Hero: Part of the First Draft of A Portrait of the Artist as a Young Man, ed. Theodore Spencer, rev. edn (London: Paladin, 1991), 82.

${ }^{171}$ Ellmann, The Poetics of Impersonality, 198; see also Burke, The Death and Return of the Author. 
these figures, Ellmann writes, is as 'the workshop of the self' - a space in which 'personal identity is both constructed and dismantled'. ${ }^{172}$

Rethinking popular song as a possible locus of autobiography offers a way out of the critical impasse reached by both the performance studies and impersonalist paradigms. Rather than diminishing the poetic value of songs by attributing them to what Hampton depicts as 'the vagaries of biography', ${ }^{173}$ I have argued that we might hear songs in precisely the reverse terms as complex acts of autobiographical making, manifestations of an impulse through which life is shaped by a process of 'Orphic' expression. Through song, singer-songwriters can become active readers of their own experience, transforming it through poetic language, musical technique and theatrical flair to the extent that we hear their songs as introspective or confessional precisely because they are the result of conscientious craft and 'communicative virtuosity'. ${ }^{174}$ Although Shumway reminds us that owing to art's inevitable artificiality it is only within the realm of the artificial that the category of the authentic has any meaning', we should not forget that artifice can also be a conduit for subjectivity. ${ }^{175}$ That is, truth and trickery are not at odds, but exist in a mutually supportive bond: realism requires the techniques of artifice; the techniques of artifice give birth to realism. This is the conjunction that singer-songwriters consciously and continually renegotiate, traversing and obscuring the interstices between experience and imagination.

172 Ellmann, The Poetics of Impersonality, 198, ix.

173 Hampton, Bob Dylan's Poetics, 22.

${ }^{174}$ Richard Bauman, A World of Others' Words: Cross-Cultural Perspectives on Intertextuality (Malden, MA: Blackwell, 2004), 9.

175 Shumway, 'Authenticity', 532. 